\title{
QUEM DEFENDERÁ A SOCIEDADE? TRAJETÓRIAS E COMPETIÇÃO INSTITUCIONAL EM TORNO DA TUTELA COLETIVA ENTRE MINISTÉRIO PÚBLICO E DEFENSORIA NO PÓS-19881
}

\author{
WHO WILL DEFEND SOCIETY? TRAJECTORIES AND INSTITUTIONAL COMPETITION AROUND \\ COLLECTIVE REDRESS BETWEEN PUBLIC PROSECUTOR'S OFFICE AND PUBLIC DEFENDER'S \\ OFFICE IN THE POST 1988 PERIOD
}

Bruno Lamenha ${ }^{2}$

Flávia Santiago Lima ${ }^{3}$

\begin{abstract}
Resumo: A ordem constitucional de 1988 promoveu significativas mudanças no âmbito do sistema de justiça. Este artigo aborda duas instituições nele inseridas, suas trajetórias após a promulgação do texto constitucional, apresentando uma hipótese de competição institucional entre ambas em torno de uma agenda igualmente cara à CRFB/88: a defesa de direitos coletivos, difusos e individuais homogêneos (tutela coletiva). Assim, em que pese o quadro institucional desenhado pelo Constituinte de 1987/1988 tenha estabelecido funções muito distintas para o Ministério Público e a Defensoria Pública, passados mais três décadas desde a CRFB/88, verifica-se uma clara superposição de atribuições no campo da tutela coletiva entre as duas instituições. Esteado na tradição do (neo)institucionalismo histórico, analisando as trajetórias - formais e informais - de reconformação de ambas as instituições, o texto identifica processos paralelos de mudança institucional no Ministério Público e na Defensoria Pública que estabelecem algumas hipóteses explicativas para a competição estabelecida entre os dois órgãos no âmbito da tutela coletiva. A pesquisa é bibliográfica, com amparo na revisão de literatura produzida no Direito e na Ciência Política quanto ao tema e análise documental (legislação, atas e discursos), numa perspectiva interdisciplinar. Palavras-chave: Ministério Público. Defensoria Pública. Tutela Coletiva. Institucionalismo Histórico. Competição institucional. Mudança institucional.
\end{abstract}

\begin{abstract}
The 1988 constitutional order promoted significant changes within the justice system. This article addresses two institutions inserted in this scenario, their trajectories after the promulgation of the constitutional text, presenting a hypothesis of institutional competition between them around an also valuable agenda in the 1988 Constitution: the defense of transindividual rights (collective redress). Thus, in spite of the institutional framework designed by the Constituent of 1987/1988 having established very different functions for the Public Prosecutor's Office and the Public Defender's Office, three more decades since 1988 Constitution, there is a clear overlap of attributions in the field of collective redress between these two institutions. Based on the tradition of historical (neo) institutionalism, analyzing the trajectories - formal and informal - of reorganization of both institutions, the text identifies parallel processes of institutional change in the Public Prosecutor's Office and the Public Defender's Office that establish some explanatory hypotheses for the competition established between them within the scope of collective redress. The research is based in a bibliographic approach, supported by the literature review produced in Law and Political Science regarding the theme and documentary analysis (legislation, minutes and speeches), in an interdisciplinary perspective.
\end{abstract}

Keywords: Public Prosecutor's Office. Public Defender's Office. Collective Redress. Historical Institutionalism. Institutional Competition. Institutional Change.

Recebido em 17 de novembro de 2020 Avaliado em 25 de novembro de 2020 (AVALIADOR A) Avaliado em 24 de maio de 2021 (AVALIADOR B) Aceito em 24 de maio de 2021

\footnotetext{
1 Agradecemos à inestimável contribuição dos pareceristas da publicação para o aperfeiçoamento deste artigo.

2 Mestre em Direito Público pela Universidade Federal de Alagoas; doutorando em Direito pela Universidade Federal de Pernambuco; https://orcid.org/0000-0002-6655-2735; brunolamenha@uol.com.br

3 Mestre e Doutora em Direito Público pela Universidade Federal de Pernambuco; Professora da Universidade de Pernambuco e do Programa de Mestrado da Faculdade Damas; http://orcid.org/0000-0002-6995-0982; flavia-santiago@uol.com.br
} 


\section{Introdução}

A defesa de direitos coletivos, difusos e individuais homogêneos é considerada uma das principais inovações jurídicas do longo do processo de redemocratização política e consolidação institucional das últimas décadas no Brasil. Celebrada como conquista da cidadania e marco do movimento de acesso à justiça, a tutela coletiva constitui-se num dos fundamentos para a aproximação entre sociedade civil e sistema de justiça, com consequências para os arranjos destas instituições.

Propõe-se, como hipótese de trabalho, que a atribuição da tutela coletiva foi estratégica para a construção do perfil institucional do Ministério Público (MP) e para a sua trajetória ao longo das décadas de 1990 e 2000, na qual a instituição acumulou significativo capital político e importante projeção social. No percurso desde 1988, identifica-se uma inflexão nas prioridades institucionais do MP após esse primeiro momento de intensificação da atuação no campo da tutela coletiva, com a retomada de um certo protagonismo no âmbito penal, especificamente no campo anticorrupção. Argumenta-se, a esse respeito, a ocorrência de uma mudança institucional informal no campo das prioridades institucionais do MP, fenômeno que se tornou mais visível a partir de meados dos anos $2000.4,5$

A Defensoria Pública (DP), por sua vez, sofreu grande resistência à agenda mobilizada pelos defensores e assistentes judiciários estaduais ao tempo da constitucionalização da instituição, na Constituição Federal de 1988 (CRFB/88). Neste sentido, é importante historiar o resgate, pela DP, das pautas bloqueadas na Assembleia Nacional Constituinte de 1987-1988 (ANC) através de um progressivo movimento de alterações legislativas que culminaram no seu atual perfil institucional, profundamente associado à reivindicação de atribuições no campo dos direitos transindividuais.

A agenda em torno da tutela coletiva no processo de construção do MP de 1988 e nas mudanças institucionais da DP no período posterior a 1988 não é acidental. A defesa de direitos

\footnotetext{
${ }_{4}$ Conforme se advertirá mais detidamente a seguir, considerando a pluralidade de institucionais ministeriais e defensoriais nos diferentes níveis do sistema de justiça, há uma limitação na identificação de marcos temporais precisos para o registro de elementos indicativos de mudanças institucionais que sejam contemporâneas a todos os órgãos estaduais e federais do MP e da DP. O que o texto argumenta é que, apesar dessa dificuldade, há evidências de que houve uma mudança gradual de agenda corporativa comum com reflexos, até mesmo, no plano atitudinal (em relação, sobretudo, à autovisão dos promotores e procuradores em relação à corporação e a sua própria atuação) difusamente partilhada por todo Ministério Público brasileiro.

5 A referência temporal a "meados dos anos 2000" é mobilizada por diversos autores que pesquisam a trajetória do Ministério Público de 1988. A título exemplificativo, Avritzer e Marona (2017, p. 366) pontificam, sobre o Ministério Público e essa mudança de prioridades, que "de fato, a partir dos anos 2000, a via criminal começou a parecer mais atrativa, particularmente depois da 'reabilitação do prestígio do inquérito policial', que veio à reboque do enorme incremento institucional que a polícia judiciária experimentou, particularmente a Polícia Federal”. Não se pode perder de vista que, por vezes, o foco privilegiado da literatura tem sido a experiência do Ministério Público Federal, dado o seu caráter nacional, obnubilando a experiência particular dos MPs dos estados e do DF. Isso não significa, no entanto, que o fenômeno descrito não se faça sentir no âmbito destes últimos, conforme Lemgruber et al. (2016) demonstram através de um survey de dimensões nacionais acerca da visão dos membros do MP acerca da instituição e de sua atuação e Sampaio e Viegas (2019, p. 13), a partir dos dados de produtividade do Conselho Nacional do Ministério Público dos anos de 2015 a 2017. Tais achados serão expostos com mais vagar no decorrer do texto.
} 
transindividuais em uma sociedade estruturalmente desigual, como a brasileira, é capaz de mobilizar uma imagem institucional positiva e, por conseguinte, maior visibilidade e capital político. Sob certo aspecto, a atuação neste campo é capaz de alçar tais instituições a uma posição de mediadoras da cidadania, mas também indica a necessidade de um arcabouço jurídico de independência e insulamento das pressões políticas contrárias às pautas transindividuais, o que pode sugerir competições entre os responsáveis pela tutela coletiva, em busca de sua titularidade única. Não é por acaso, portanto, que, ao longo das décadas que se seguiram a 1988, o MP tenha sido um dos principais atores a tentar bloquear - sem sucesso - a expansão das atribuições da DP nesta direção, ainda que, paralelamente a esse processo, o próprio Ministério Público tenha relegado a tutela coletiva a um papel secundário na agenda de construção de sua imagem institucional.

Neste sentido, haveria um processo de aproximação e, até mesmo, superposição de funções entre Ministério Público e Defensoria Pública no âmbito da tutela coletiva? Para responder à pergunta de pesquisa proposta, o artigo tem como objeto a análise das trajetórias de ambas as instituições, nas décadas que se seguiram ao momento constituinte. A hipótese geral é de que a tutela coletiva se converteu numa ratio mobilizada para a formatação de instituições autônomas e garantia de independência aos membros do sistema de justiça, conforme proposto por parte significativa da literatura sobre o Ministério Público ${ }^{6}$ e é possível deduzir tanto a partir das inovações legislativas associadas ao MP nas décadas que antecederam à Constituinte ${ }^{7}$ quanto da interação do órgão com setores da sociedade civil organizada de então ${ }^{8}$. raciocínio se estende à Defensoria Pública,

\footnotetext{
6 Neste sentido, Rogério Arantes (2002, p. 35) argumenta que a mobilização da agenda corporativa do MP, nas décadas de 1970 e 1980, na direção da assunção de uma função central na defesa dos nascentes direitos de natureza difusa, coletiva ou individual homogênea constituiu um "ponto de inflexão da virada histórica do Ministério Público" na direção do perfil institucional assumido pelo órgão em 1988.

7 Carvalho e Leitão (2010, p. 400) destacam como a intervenção obrigatória do MP em matérias que versassem sobre "interesse público", estabelecida no art. 82, III, do Código de Processo Civil de 1973, abriu uma discussão em torno dessa categoria aberta e sem maiores delimitações semânticas, permitindo que setores reformistas da comunidade jurídica, e a agenda corporativa do próprio MP - que, à época, não contava com uma mobilização nacional, tendo por principal expressão a Associação Paulista do Ministério Público (APMP) - passassem a sustentar que a defesa de interesses sociais e individuais indisponíveis estava abrangido na categoria. Este ponto é interessante, uma vez que, a intenção original do legislador processual civil dizia respeito, tão-somente, à fiscalização do interesse patrimonial das pessoas jurídicas de direito público (ARANTES, 2002, p. 32-33). No período pré-1988, vários outros movimentos legislativos merecem referência, tais como: i) a Emenda Constitucional n. 7/1977, que alterou a Constituição autoritária de 1967, e previu uma lei orgânica nacional para o MP (art. 96, p. único); ii) a previsão, na LC 40/1981, primeira lei orgânica nacional do MP, da "iniciativa para ação civil pública" como uma das atribuições do órgão, com expressa previsão da "defesa da ordem jurídica e dos interesse indisponíveis da sociedade" como uma das funções ministeriais (v. arts. $\left.1^{\circ}, 3^{\circ}, \mathrm{III}\right)$. As duas legislações, lembra Cabral Netto (2009, p. 40), foram objeto de intenso lobby da Confederação das Associações Estaduais do Ministério Público (CAEMP), antecessora da Associação Nacional do Ministério Público (CONAMP).

8 Aqui, Maciel e Koerner (2014, p. 114) destacam que "as estratégias e alianças adotadas pelo movimento associativo do MP, a partir de 1974, foram relevantes para a conquista da independência institucional e do novo papel da Constituição de 1988. Em primeiro lugar, a construção doutrinária da noção de interesse público, acompanhada do engajamento nas mobilizações ambientalistas, foi transformando o MP numa alternativa institucional viável e disponível, naquele momento, para canalizar os novos problemas e conflitos sociais. Em segundo lugar, a interação com as redes pró-democracia contribuiu para ampliar o padrão tradicional de alianças, bem como as estratégias de mobilização para além do lobby. Nesse processo, o MP atraiu para si visibilidade pública inédita que se converteu no apoio político de grupos, movimentos sociais, comunidade científica e meios de comunicação ao perfil potencialmente politizado de atuação profissional". Dois frutos deste processo descrito pelos autores são a Lei da Política Nacional do Meio Ambiente (Lei n. 6.938/81), que conferiu ao MP a legitimidade exclusiva para promover a responsabilização civil e criminal por danos causados ao meio ambiente (CARVALHO; LEITÃO, 2010) e a própria Lei n. 7.347/85, a Lei da Ação Civil Pública, que estabeleceu o MP como um dos legitimados ativos para a
} 
portanto, uma vez que o desenvolvimento do texto indica a existência de elementos que identificam a mobilização de uma trajetória institucional bastante similar do órgão, a partir de suas funções "clássicas" na direção de arrogar para si atribuições também no campo dos direitos transindividuais.

Adota-se, como marco teórico, o institucionalismo histórico, por salientar as conexões entre comportamentos individuais e mudanças institucionais, assimetrias de poder no desenvolvimento destas, além de enfatizar as trajetórias (path dependence) e suas consequências intencionais ou não, avaliando seus resultados políticos (HALL; TAYLOR, 1996, p. 938).

Neste sentido, destaca-se a perspectiva de que o ativismo político de agentes estatais - ou seja, a mobilização das elites jurídicas em torno de uma agenda específica - é um aspecto central para refletir a respeito do marco normativo original e nas mudanças institucionais ocorridas na DP e no MP após a promulgação da CRFB/88 e que não necessariamente está relacionado a uma melhor eficiência na concretização de velhas atribuições e das novas funções as quais se reivindica (ARANTES, 2015, p. 30).

O segundo ponto está relacionado à temática da mudança institucional. Aqui, propõese que, diferente da abordagem institucionalista mais convencional, mudanças institucionais não exigem, necessariamente, alterações formais nas regras que organizam o desenho e o funcionamento da instituição, podendo ocorrer, inclusive, gradualmente e a partir do desenvolvimento de processos informais e internos (MAHONEY; THELEN, 2010, p. 4-14).

Assim, o texto descreve os aspectos gerais do marco normativo original de MP e DP na CRFB/88, para avançar nas discussões em torno de mudanças institucionais formais e informais, categoria de análise relevante para pensar a interação e a competição entre as instituições do sistema de justiça no Brasil. Deste quadro geral, passa-se à análise das trajetórias especificas destas instituições: as sucessivas normativas que alteraram o perfil institucional da DP, na agenda original de autonomia e independência e ampliação das suas atribuições; e, no caso do MP, as alterações no campo de suas prioridades institucionais, do campo da tutela coletiva para o combate à corrupção no âmbito penal.

Antes de prosseguir, uma dificuldade adicional merece ser mencionada. Ministério Público (MP) e Defensoria Pública (DP) não são uma mesma instituição nos diferentes níveis do sistema de justiça brasileiro. Há, na realidade, dezenas de órgãos do MP e da DP, considerada a sua organização particular nas unidades da Federação (UFs) e também no plano federal ${ }^{9}$. Nesta esteira,

propositura da ACP (art. $5^{\circ}$ ) e o único com atribuição de instaurar o inquérito civil prévio (art. $8^{\circ}$, par. $1^{\circ}$ ). Aqui, também este ativamente presente a agenda corporativa do MP à época, sendo sintomático o registro, na exposição de motivos do projeto da lei de ACP, a "colaboração prestimosa" de membros do Ministério Público de São Paulo ao texto submetido ao Parlamento (ARANTES, 2002, p. 61).

9 Quanto ao MP, além dos 26 (vinte e seis) órgãos ministeriais estaduais, o Ministério Público da União (MPU) se desdobra, além do Ministério Público Federal (MPF) e do MPDFT (Ministério Público do Distrito Federal e Territórios), em dois órgãos ministeriais de temática particular: o Ministério Público do Trabalho (MPT) e o Ministério Público Militar (MPM), totalizando 30 (trinta) instituições distintas. Exclui-se dessa contagem os chamados Ministérios Públicos de Contas, uma vez que se trata de órgãos inseridos na estrutura dos Tribunais de Contas e não instituições ministeriais autônomas. No 
é esperado que órgãos diferentes possam espelhar infraestruturas, regramentos internos e culturas institucionais variadas. Este alerta é particularmente importante no caso do MP, por se tratar de uma instituição mais longeva comparativamente à DP, que somente foi nacionalmente estruturada e constitucionalizada com a CRFB/88.

A tentativa de traçar uma trajetória institucional comum, portanto, envolve limitações inerentes a essa pluralidade institucional, sendo o esforço desta análise o de mapear elementos associados a uma certa trajetória institucional comum de um modelo nacional de ambas as instituições, calcado, sobretudo, a partir de seu marco normativo constitucional. Evidentemente, este esforço não exclui (apenas reforça) a relevância de abordagens particulares em relação a determinado órgão do MP ou da DP a serem desenvolvidas em outras frentes de pesquisa. Argumenta-se, assim, que a viabilidade e a utilidade do mapeamento ora proposto e desenvolvido no decorrer do texto se esteia, sobretudo, na existência de um marco normativo único nas legislações de regência de ambas instituições - seja a própria Constituição Federal, quanto as LC 80/94 (Lei Orgânica da Defensoria Pública) e Lei n. 8.625/93 (Lei Orgânica do Ministério Público) -, além de instâncias associativas de caráter nacional capazes de promover a coordenação e a articulação de uma agenda institucional única ${ }^{10}$ (MADEIRA, 2014, p. 56).

\section{Duas instituições em (des)harmonia: o marco normativo original de MP e DP na CRFB/88}

$\mathrm{O}$ ativismo político de agentes estatais, aqui notadamente no âmbito do sistema de justiça, é um fenômeno pouco explorado pela análise institucionalista (MOREIRA, 2016, p. 49-50). A literatura especializada, no entanto, propõe que o desenho institucional assumido por instituições do sistema de justiça, como o Ministério Público (MP) e a Defensoria Pública (DP), no quadro normativo da Constituição de 1988 (CRFB/88) está intimamente associado, entre outros aspectos, às agendas mobilizadas pelas elites jurídicas a partir da conjuntura política e social da época (MACIEL; KOERNER, 2014, p. 113-114; MOREIRA, 2016, p. 75-76).

Embora do ponto de vista normativo-constitucional seja possível objetar que, enquanto a DP foi constitucionalizada apenas em 1988, o MP possuiria uma perenidade institucional mais estabelecida na história republicana nacional, parece correto afirmar que a CRFB/88 representou

caso da DP, são 28 (vinte e oito) órgãos ao todo: uma Defensoria Pública da União (DPU) e 27 (vinte e sete) defensorias estaduais (DPEs).

10 Observe-se, por exemplo, a Associação Nacional de Membros do Ministério Público (CONAMP) e a Associação Nacional das Defensoras e Defensores Públicos (ANADEP), associações civis de caráter nacional que agregam membros de todas as carreiras do MP e da DP respectivamente; e ainda, o Conselho Nacional de Procuradores-Gerais (CNPG) e o Colégio Nacional de Defensores Públicos Gerais, ambas entidades associativas que reúnem os chefes de carreira dos diferentes órgãos do MP e da DP em todo território nacional. 
o ponto de chegada de um longo processo de mudança institucional formal, ${ }^{11}$ iniciado em meados da década de 1970, ${ }^{12}$ e que assegurou uma identidade institucional e normativa consolidada para o órgão (ARANTES, 2002, p. 76; SAUWEN FILHO, 1999, p. 165-169).

Como amplamente explorado pela literatura especializada (ARANTES, 2002; KERCHE, 2009; RIBEIRO, 2017; SADEK, 2000), o MP de 1988 produziu uma instituição com perfil absolutamente singular ${ }^{13}$ e a ampla reengenharia de atribuições e prerrogativas esteve intimamente relacionada com o afirmação de atribuições para além da clássica função de persecução penal, típica do MP, especialmente no que diz respeito à atuação no âmbito da defesa de direitos coletivos, difusos e individuais homogêneos, ${ }^{14}$ a chamada tutela coletiva (ARANTES, 2002, p. 50).

A constitucionalização da Defensoria Pública em 1988, por sua vez, encontrou maiores dificuldades que a trajetória percorrida pelo MP. A agenda dos defensores e dos assistentes judiciários que atuavam no âmbito dos Estados estava relacionada, em linhas gerais, à criação de uma instituição de caráter nacional, com a mesma estatura de prerrogativas do MP, e com a função precípua de promover a orientação jurídica e defesa dos necessitados.

No contexto da Assembleia Nacional Constituinte de 1987-1988 (ANC), todavia, houve resistências da parte de outras corporações jurídicas às pretensões defensoriais, especialmente as mobilizadas pelas procuradorias estaduais, pela OAB e pelo próprio MP (MOREIRA, 2016, p. 78). Esse cenário de competição institucional é um elemento importante para compreende o porquê de, somente em 2012, todos os estados da Federação passarem a contar com uma DP estadual em seus respectivos sistemas de justiça, apesar do marco constitucional estabelecido em 1988.

De todo modo, o quadro normativo original da CRFB/88 estabeleceu uma divisão de atribuições bem delimitada entre MP e DP. No âmbito criminal, ambas as instituições foram colocadas em polos opostos: o MP como titular da ação penal pública e a DP na defesa dos que, por razões econômicas, não pudessem contratar os serviços de um advogado privado. No âmbito cível, a atuação do MP estaria, majoritariamente, associada à defesa de direitos transindividuais, enquanto

\footnotetext{
${ }^{11}$ Não há consenso na literatura quanto às razões do sucesso político da agenda ministerial na busca de fortalecimento institucional a partir da tutela coletiva (CARVALHO; LEITÃO, 2010, p. 404-408). A melhor leitura parece combinar múltiplos aspectos (LAMENHA, 2019), tais como o lobby institucional bem organizado (ARANTES, 2002, p. 77), a existência de uma conjuntura ideológica e política favorável à concessão de independência de amplos poderes para promover o interesse social a uma instituição fora do jogo político-eleitoral ordinário (KERCHE, 2009, p. 23) e a articulação com atores externos ao sistema de justiça, nomeadamente com a sociedade civil organizada durante o processo transicional brasileiro (KOERNER; MACIEL, 2014, p. 113-114).

12 Referimo-nos, especificamente, à inserção, no art. 82, III, do Código de Processo Civil de 1973 da atribuição explícita do MP em intervir, obrigatoriamente, em todas as causas que versassem sobre interesse público (ARANTES, 2002, p. 32-33; CARVALHO; LEITÃO, 2010, p. 400). As notas de rodapé n. 5 e 6 desenvolvem, com mais detalhes, este ponto.

${ }^{13}$ Não é incomum, na literatura, a referência ao perfil "único no mundo" legado pelo Constituinte de 1987-1988 ao MP (NÓBREGA, 2007, p. 64).

${ }^{14}$ Apesar de existir significativa discussão na literatura especializada a respeito, é suficiente para os propósitos deste texto diferenciar "direitos difusos", "direitos coletivos" e "direitos individuais homogêneos" no marco do art. 81, p. único, do Código de Defesa do Consumidor. Assim: i) direitos difusos são direitos transindividuais, "de natureza indivisível, de que sejam titulares pessoais indeterminadas e ligadas por circunstâncias de fato'; ii) direitos coletivos são direitos "de natureza indivisível, de que seja titular grupo, categoria ou classe de pessoas ligadas entre si ou com parte contrária por uma relação jurídica base; iii) direitos individuais homogêneos são direitos individuais equiparados à condição de direitos transindividuais em razão da "origem comum" que conecta todos os seus titulares;
} 
a DP atuaria na tutela individual dos necessitados (BRASIL, 1988). Assim, parece acertado propor que, ao final do processo constituinte, as duas instituições foram eficientes em reivindicar para si um campo importante de um movimento mais amplo, de cariz internacional, de fortalecimento das instituições judiciais, de acesso à justiça e de coletivização de direitos (CAPPELLETTI; GARTH, 1988).

\section{Pluralismo estatal e mudança institucional}

Evidentemente, instituições não constituem o único elemento explicativo relevante da vida política (HALL; TAYLOR, 2003, p. 201). No entanto, os casos de MP e DP ilustram que é acertada a abordagem que considera os atores estatais (e não apenas os atores não estatais) como capazes de mobilizar seus próprios interesses para influenciar na concepção de um desenho institucional ou de uma política pública (SKOCPOL, 1985).

No caso da institucionalidade brasileira, Rogério Arantes (2015, p. 30) sugere que, ao lado das formas tradicionais de pluralismo político, por meio das quais os atores e grupos sociais mobilizam suas demandas frente ao Estado, desenvolveu-se uma espécie de "pluralismo estatal", isto é, um fenômeno associado ao planejamento e à consecução de metas institucionais específicas em prol da criação e/ou mudança institucional em organismos estatais a partir de demandas capitaneadas por atores, grupos e corporações no interior do próprio Estado (e não apenas atores extraestatais, como é usual nas explicações das teorias institucionalistas). Tais projetos particularistas de poder são mediados, no mais das vezes, por uma linguagem de direitos e/ou de transparência, associando-os a um melhor funcionamento das instituições (ARANTES, 2015, p. 30).

Arantes (2015, p. 45) estruturou a referida categoria para pensar a interação entre MP, Polícia Federal e demais órgãos associados à accountability das instituições estatais. Em síntese, argumenta que a existência de várias instituições e, consequentemente, múltiplas agendas para a consecução de maior espaço, recursos e atribuições força a necessidade de modificações constantes nas regras de funcionamento do sistema de fiscalização dos poderes públicos, em razão dos choques e conflitos institucionais inevitáveis.

Propõe-se que o fenômeno do pluralismo estatal pode ser uma chave analítica para pensar como a atribuição no campo da tutela coletiva, em especial a legitimidade para a propositura do seu principal instrumento judicial, a ação civil pública (ACP), tem sido mobilizada ao longo do tempo por MP e DP. Parece uma estratégia útil, portanto, observar como essas instituições organizaram suas agendas políticas no sentido de reforçar ou ampliar suas atribuições e ainda como construíram os sentidos e as prioridades na construção de sua imagem pública e na atuação em suas respectivas atividades-fim.

Nesse aspecto, os processos que viabilizam mudanças institucionais não passam, necessariamente, por uma alteração no marco normativo da instituição. Mantida a estrutura 
normativa, processos informais podem alterar os sentidos e as prioridades de determinada instituição. Além disso, essas alterações no funcionamento da instituição tampouco exigem uma ruptura ou choque institucional provocado por um fator exógeno, como é normalmente abordado na análise institucionalista. Mudanças institucionais graduais - e algumas vezes, sem alteração substancial do próprio marco normativo - podem modificar significativamente o perfil de uma instituição ao longo do tempo. Assim, toma-se como formal o processo de mudança institucional que exigiu alterações nas regras que regulamentam determinada instituição e informal, o processo congênere no qual tais modificações de marco normativo não se verificaram (MAHONEY; THELEN, 2010, p. 4-14).

Os próximos tópicos deste artigo abordarão, separadamente, os processos de mudança institucional de MP e DP em torno da tutela coletiva nas décadas posteriores à promulgação da CRFB/88, evidenciando o quão distintas foram as duas trajetórias, não apenas em relação a seu resultado final. No caso da Defensoria Pública, tem-se um claro processo de mudança institucional formal: as sucessivas alterações constitucionais e legislativas tornaram possível um novo marco normativo capaz de alterar o perfil institucional do órgão, não só concretizando sua agenda original de autonomia e independência, mas avançando em relação a outras atribuições, como a defesa de direitos transindividuais.

Quanto ao Ministério Público, embora não tenha havido uma alteração substancial em seu desenho institucional, elementos internos e externos ao órgão (LONDERO, 2019) tornaram possível que se especule sobre uma possível e progressiva alteração de suas prioridades institucionais do campo da tutela coletiva para o combate à corrupção, especialmente no seu aspecto penal. Propõe-se, portanto, que a trajetória do MP nos anos posteriores a 1988 é um exemplo de mudança institucional informal.

\section{Defensoria Pública, um exemplo de mudança institucional formal: da busca por autonomia à ampliação das atribuições}

\subsection{A agenda defensorial como espelho da trajetória do MP}

Os debates na ANC deixaram claro que a agenda de construção de uma DP como instituição permanente e de caráter nacional tinha como referência institucional o Ministério Público. Segundo Moreira (2016, p. 102-103), isso decorre, sobretudo, do fato de que o modelo nacional de Defensoria espelhou a experiência fluminense e a Defensoria Pública do Rio de Janeiro permaneceu, durante mais de 20 (vinte) anos, funcionalmente vinculada ao MP estadual.

Embora a configuração normativa atual do MP, em termos de autonomia, atribuições e independência, e a definição de um marco normativo nacional remontem a um processo iniciado na década de 1970 e concluído com a CRFB/88, a instituição sempre figurou explicitamente no 
quadro geral dos órgãos do sistema de justiça durante todo o período republicano, ${ }^{15,16}$ notadamente a partir de sua função típica de persecução criminal. Assim, ainda que fosse inexistente o histórico da própria DP como funcionalmente vinculada ao MP, a longevidade desta última instituição, apesar das descontinuidades em termos de modelo institucional, seria uma referência obrigatória para qualquer órgão que pretendesse se estabelecer como uma instituição permanente em um campo (o sistema de justiça) com um evidente protagonista, o Poder Judiciário.

Um outro aspecto a considerar, como recorrentemente referido pelos representantes da Federação Nacional dos Defensores Públicos (FENADEP) nos debates na ANC (BRASIL, 1987, p. 100), é que a função pública defensorial foi pensada e proposta como antípoda da função pública acusatória no âmbito do processo criminal, de maneira que se o Estado estrutura uma instituição permanente para acusar, deveria estruturar, em igualdade de condições, um órgão congênere para a função de defesa.

Traçado esse cenário, e considerando a evidência de que certos processos de construção institucional tendem a uma dependência da trajetória percorrida (path dependence), notadamente quando o percurso oferece aos atores envolvidos ganhos crescentes que desincentivam a quebra ou reversão do trajeto (HALL; TAYLOR, 2003, p. 200; MAHONEY, 2000, p. 510-512; MOREIRA, 2016, p. 60-61), propõe-se que, após a CRFB/88, a agenda da DP quanto à busca por autonomia, independência e mais atribuições continuou espelhando o modelo ministerial e essa é uma chave analítica importante para entender os porquês da DP ter reivindicado novas atribuições no campo da tutela coletiva e também na defesa dos direitos humanos.

\subsection{Os bloqueios na promulgação da LC n. 80/94 e o direcionamento da agenda defensorial para 0 âmbito estadual}

Em 1994, no governo Itamar Franco, foi promulgada a Lei Complementar n. 80, regulamentando o art. 134, parágrafo único da CRFB/88 e estabelecendo, pela primeira vez, um marco normativo nacional para a DP. O art. $3^{\circ}$ da LC prevê que os princípios institucionais da DP são a unidade, a indivisibilidade e a independência funcional, reproduzindo textualmente o art. 127,

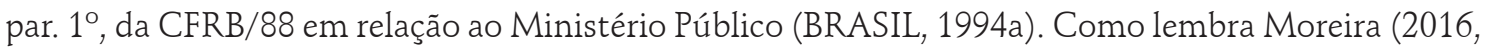
p. 102), essa foi umas disposições que os defensores e assistentes judiciários não conseguiram incluir no texto final da CRFB/88.

\footnotetext{
15 O Decreto n. 848, de 11.10.1890, que regulamentava o funcionamento da Justiça Federal, dispõe em seu capítulo VI sobre o Ministério Público, estatuindo funções ao Procurador-Geral da República e aos procuradores da República. A exposição de motivos do citado ato normativo pontuava que o "Ministério Público é uma instituição necessária em toda organização democrática e imposta pelas boas normas da Justiça." (SAUWEN FILHO, 1999, p. 127).

${ }^{16}$ A referência ao Ministério Público no âmbito do sistema de justiça também ocorre nos períodos da administração colonial portuguesa e do Império, no entanto, esse escorço histórico parece desnecessário aos propósitos do artigo (SAUWEN FILHO, 1999, p. 110-123).
} 
Vários vetos, contudo, foram aplicados a dispositivos da LC n. 80/94. A maior parte deles se refere a previsões que buscavam aproximar a DP do quadro institucional e das prerrogativas dos membros do MP. Especificamente em relação à tutela coletiva, o art. 4 ${ }^{\circ}$ XII, da LC 80/94 previa, como função institucional da DP, "patrocinar ação civil pública, em favor das associações que incluam entre suas finalidades estatutárias a defesa do meio ambiente e a proteção de outros interesses difusos e coletivos." (BRASIL, 1994b).

Nas razões de veto, o Presidente da República consigna que a atribuição se afasta da finalidade institucional da DP, uma vez que associações "não podem ser atendidas como 'necessitados' para o fim de concessão da gratuidade da justiça." (BRASIL, 1994b). O mais curioso, todavia, é que o chefe do Executivo invoca razões apresentadas pelo Procuradoria-Geral da República se opondo ao dispositivo aprovado pelo Congresso Nacional.

Trata-se de um expediente pouquíssimo usual em relação às funções institucionais do Procurador-Geral da República (PGR) que, desde a CRFB/88, com a criação da Advocacia-Geral da União (AGU), não detém qualquer atribuição no campo da advocacia estatal. Quanto à questão da legitimidade na ACP reivindicada pela DP, o então PGR, Aristides Junqueira, apresentou três razões fundamentais: (i) a função típica da Defensoria Pública seria a defesa de direitos individuais e a atuação na tutela coletiva tiraria o foco da instituição da defesa dos necessitados individualmente considerados; (ii) a possibilidade de representação de associações pela DP minaria um dos objetivos da Lei da ACP quanto a uma maior participação da sociedade civil em questões coletivas "sem a tutela de qualquer ente estatal"; (iii) quando necessária a participação do Estado na defesa de direitos coletivos, a CRFB/88 já tinha definido expressamente um órgão: o Ministério Público (BRASIL, 1994b).

De mais a mais, entre outras disposições vetadas na LC 80/94, constava a atribuição para "homologar transações extrajudiciais" que passariam a ter força de título executivo extrajudicial (art. $4^{\circ}$, XIII e $\ 3^{\circ}$ ) o que viabilizaria a celebração, pela Defensoria Pública, de Termos de Ajustamento de Conduta (TACs), conforme autorizava o art. $5^{\circ}$, $\mathbb{S} 6^{\circ}$, da Lei n. 7.347/8517 aos legitimados ativos para a propositura da ação civil pública. Outros dispositivos vetados envolviam a autonomia administrativa e funcional do órgão (art. $3^{\circ}$, p. único), a defesa da criança e do adolescente (art. $4^{\circ}$, $\left.\mathbb{S} 1^{\circ}\right)$, a equiparação dos critérios de remuneração dos Defensores às carreiras previstas no Título IV, Capítulo IV da CRFB/88, referente às funções essenciais à Justiça, cujo principal marco normativo é o do MP (art. 39, $\mathbb{S} 1^{\circ}$ ), além de diversas garantias e prerrogativas asseguradas ao membro do MP, como foro de prerrogativa de função, livre trânsito no exercício da função e porte de arma independentemente de autorização (BRASIL, 1994b).

Segundo a literatura especializada, os bloqueios exercidos especialmente pelo MP cristalizados na promulgação da LC 80/94 direcionou a agenda corporativa defensorial para ao plano estatual, com objetivo de instalação e estruturação dos órgãos nas unidades federadas (MOREIRA,

\footnotetext{
$\overline{17}$ A inclusão deste dispositivo na Lei da ACP se deu através da promulgação do Código de Defesa do Consumidor (Lei n. 8.078/90).
} 
2016, p. 104), processo que se revelou longo e tortuoso, especialmente em razão da resistência de outros atores do sistema de justiça, especialmente a $O A B$.

\subsection{0 longo hiato: da EC 45/2004 à EC 74/2013}

Em estudo sobre a institucionalização e independência dos órgãos estaduais da DP, Lígia M. Madeira (2014, p. 61-62) ${ }^{18}$ identifica a Emenda Constitucional n. 45/04, a chamada Reforma do Judiciário, como um ponto de inflexão para a consolidação e autonomia das DPs estaduais. Nas vésperas da reforma, em 2004, havia 22 órgãos estaduais dentre 27 possíveis, mas apenas 5 (cinco) poderiam ser considerados como independentes (Acre, Ceará, Mato Grosso do Sul, Mato Grosso e Rio de Janeiro). Três anos depois (2009), o número de DPs estaduais consideradas independentes aumentou para 10 (dez).

Para a DP, a grande novidade viabilizada pela EC n. 45/04 - e as discussões que a antecederam tornaram possível a rearticulação de uma agenda nacional da instituição - foi o estabelecimento do parágrafo $2^{\circ}$ do art. 134 da CRFB/88 assegurando autonomia funcional e administrativa, além de iniciativa orçamentária, às Defensorias Públicas estaduais. Também houve inclusão da Defensoria no art. 168 da CFRB/88, o que lhe assegurou o repasse das dotações orçamentárias através da sistemática do duodécimo, tal como ocorre com o Poder Judiciário e o MP (BRASIL, 2004).

Resgatando os debates legislativos referentes à Reforma do Judiciário na Câmara dos Deputados, Moreira (2016, p. 105-106) faz menção ao destaque n ${ }^{\circ} 274$, proposto por José Roberto Batochio, deputado federal por São Paulo e ex-presidente da OAB/SP, que previa o estabelecimento de um parágrafo terceiro ao art. 134 da CRFB/88, estabelecendo a possibilidade de celebração de convênios para prestação de assistência judiciária aos necessitados, independentemente da atuação da DP. A proposta, que foi rejeitada por apenas um voto na Comissão Especial da Câmara, sugere uma certa continuidade do lobby promovido por outras instituições contra a consolidação nacional das DPs, embora o principal ponto de resistência aqui fosse mobilizado pelos Estados da Federação, alegando, sobretudo, razões orçamentárias associadas à criação de uma nova instituição no âmbito do sistema de justiça (MOREIRA, 2016, p. 105-106). Neste sentido, alguns Estados opunham convênios já firmados com a $\mathrm{OAB}$ como justificativa para não criar um órgão estadual da DP, sendo paradigmático o caso já mencionado de Santa Catarina, que somente instituiu a Defensoria Pública após o julgamento de duas ADIs 3.892 e 4.270, que declararam inconstitucional dispositivo da Constituição Estadual e lei estadual que autorizavam esse tipo de expediente (BRASIL, 2012b, 2012c).

\footnotetext{
${ }_{18}$ A autora oferece uma mensuração do nível de institucionalização independência dos órgãos estaduais da DP através da análise da presença/ausência de uma série de variáveis, dentre as quais, a existência de lei orgânica estadual, escolha do Defensor-Geral por meio de lista tríplice votada pela carreira e poderes do Defensor-Geral em relação à administração do órgão. Com base na métrica proposta no estudo, divide as DPs estaduais em três grupos, quanto à independência: i) não independente (NI); ii) pouco independente (PI) e iii) autônoma (i).
} 
Além disso, o episódio demonstra os desafios à consolidação e a força institucional de um órgão cuja atribuição se limitava à orientação jurídica e defesa judicial dos necessitados. Considerando que, em muitos locais do País, havia um longo histórico de prestação desse tipo de serviço sem a presença de uma instituição pública específica, sempre pairaria sob a DP o risco de uma reversão institucional mobilizada pelo resgate a esses modelos alternativos. Essa é uma chave explicativa para pensar o quão essencial parecia à época, para agenda de consolidação da DP, a expansão de atribuições para além da tutela individual dos necessitados.

A EC 45/04, todavia, promoveu um racha entre as pautas corporativas dos órgãos defensoriais: a autonomia prevista no art. 134, par. $2^{\circ}$, não foi estendida à Defensoria Pública da União (DPU). ${ }^{19}$ À época, havia resistência da AGU à inclusão da DPU neste rol, por constituir uma assimetria entre os órgãos e, por essa razão, os representantes das DPs estaduais, através da ANADEP, advogavam a exclusão da DPU da proposta de EC para afastar o risco do dispositivo ser rejeitado integralmente. Excluída, a DPU atuou, por sua vez, para que o texto do art. 134, par. $2^{\circ}$, da CRFB/88 fosse rejeitado (MOREIRA, 2016, p. 107-108).

A correção dessa assimetria só ocorreria quase uma década depois, com a aprovação da EC n 74/2013, que incluiu o parágrafo terceiro do art. 134 da CRFB/88, para estender a autonomia administrativa e financeira, além da iniciativa orçamentária, à DPU e à Defensoria Pública do Distrito Federal (BRASIL, 2013). A Presidência da República opôs-se à Emenda Constitucional, através da propositura da ADI n. 5.296, sob a alegação de vício formal de iniciativa, já que a proposta aprovada teve origem parlamentar e, segundo a tese alegada, seria de iniciativa exclusiva do Executivo. ${ }^{20} \mathrm{O}$ pedido de medida cautelar foi negado em maio de 2016 pelo Supremo Tribunal Federal, mas a ADI continua em tramitação, aguardando julgamento de mérito. Merece registro que, na ocasião, o Procurador-Geral da República, Rodrigo Janot, em movimento que destoa da resistência habitual do MP às pretensões da DP, apresentou parecer pela improcedência do pedido (BRASIL, 2016b).

\subsection{0 ponto de virada: da Lei n. 11.448/2017 à EC 80/2014}

A Lei n. 11.448/2007 incluiu a Defensoria Pública no rol de legitimados ativos da ação civil pública, inovando no art. $5^{\circ}$ da Lei n. 7.347/85 (BRASIL, 2007). Mesmo antes desse diploma legal, havia precedentes de manejo de ACPs pela DP em casos envolvendo direitos difusos, coletivos

\footnotetext{
19 Também não foi contemplada a Defensoria Pública do Distrito Federal, que ainda não havia sido instituída e só o seria em 2012, por meio da Emenda à Lei Orgânica do Distrito Federal n. 61/2012. Merece o registro que a EC 69/2012 transferiu da União para o Distrito Federal a organização do órgão na referida unidade federada (BRASIL, 2012a).

${ }^{20}$ Moreira (2016, p. 108) situa a proposição da ADI 5.296 pela AGU na chave do pluralismo estatal, entendendo que, diante da impossibilidade de veto presidencial a propostas de EC, esse movimento viabilizou a disputa institucional em torno da questão da autonomia. Necessário ponderar, contudo, que a questão de "concorrência" entre AGU e DPU está mais associada a uma agenda que rejeitava a promoção assimétrica de prerrogativas a instituições então associadas ao Executivo federal do que propriamente a uma disputa por um mesmo campo de atribuições. De mais a mais, dificilmente o AGU ajuizaria uma ADI sem o aval da Presidência da República, aspecto que também enfraquece a tese de mera disputa de campo de atribuições.
} 
e individuais homogêneos de pessoas necessitadas. No entanto, essa legitimidade ativa era bastante discutível e, não raro, as demandas eram extintas sem resolução do mérito (MOREIRA, 2016, p. 112). Depois da autonomia concedida ao órgão, propõe-se que este é um divisor de águas para a vida institucional da DP: foi reconhecida uma ampla atribuição para a defesa de direitos coletivos, difusos e individuais homogêneos, além das demais prerrogativas asseguradas aos autores civis públicos, como a possibilidade de firmatura de TACs. De uma instituição limitada à tutela individual dos necessitados - o que constituía a sua agenda ao tempo da ANC -, a DP avançava para se colocar ao lado do MP como instituição do sistema de justiça com atribuição para atuar na tutela coletiva.

O ato normativo em questão nasceu do Projeto de Lei do Senado (PLS) n. 131/2003, de autoria do então senador fluminense Sérgio Cabral. O texto original não fazia menção à Defensoria Pública: o parlamentar propunha a extensão do rol de legitimados ativos para a ACP aos parlamentares federais, estaduais e municipais. No âmbito da Comissão de Constituição, Justiça e Cidadania (CCJ) do Senado Federal, o próprio autor da proposição apresentou a Emenda n ${ }^{\circ}$ 1-CCJ, acrescendo a Defensoria Pública ao rol de legitimados do PLS (SENADO FEDERAL, 2003).

texto foi aprovado no Senado dando ao art. $5^{\circ}$ da Lei da ACP um extenso rol de novos legitimados: o Presidente da República, as mesas da Câmara dos Deputados, Senado Federal, Assembleias Legislativas e Câmaras distrital e municipais, governadores de Estado e do Distrito Federal, o Conselho Federal da $\mathrm{OAB}$, entes da administração pública indireta nos três níveis federativos e a Defensoria Pública. Remetido à Câmara dos Deputados, o PLS foi autuado como Projeto de Lei da Câmara n. 5.704/2005. No âmbito da CCJ daquele órgão parlamentar, o relator, deputado federal Luiz Antonio Fleury Filho, apresentou substitutivo cujas razões (presentes no parecer como relator da CCJ) repudiou quase integralmente as inovações legislativas no rol de legitimados ativos da lei da ACP, entendendo que essa alteração poderia tornar a ACP "bastante vulnerável a utilizações em que prepondere o caráter político-partidário em detrimento da verdadeira defesa de interesses e direitos coletivos e difusos da sociedade." (CÂMARA DOS DEPUTADOS, 2005).

O relator, contudo, defendeu a manutenção da Defensoria Pública como legitimada ativa da ACP, citando precedente do Tribunal de Justiça do Rio Grande do Sul (AI 3274/96, Rel. Des. Luiz Odilon Bandeira, julgado em 25.02.1997) que reconheceu a legitimidade da DP para a defesa judicial dos interesses de estudantes carentes. Acrescentou ainda a "importância desta instituição e a natureza de suas atribuições sempre voltadas para a defesa dos cidadãos e para a luta pela construção neste País de um verdadeiro Estado democrático de direito." (BRASIL, 2005).

O substitutivo do deputado Fleury Filho foi aprovado pela CCJ da Câmara dos Deputados e, posteriormente, se converteu na Lei n. 11.448/07. O detalhe curioso é que Fleury Filho, expromotor de Justiça, teve longa atuação corporativa nos anos 1970 e 1980 e foi presidente da Associação Nacional do Ministério Público no período entre 1983 e 1987 (CABRAL NETTO, 2009, p. 100), operando como um dos principais articuladores do papel atribuído ao MP no campo da tutela coletiva em meados da década de 1980 e do próprio desenho institucional do MP na CRFB/88 
(ARANTES, 2002, p. 59). De mais a mais, a Lei n. 11.448/07 foi objeto de ADI n. 3.943 movida pela CONAMP, questionando a legitimidade ativa da DP para propositura da ação civil pública, tendo sido julgada improcedente pelo Supremo Tribunal Federal (BRASIL, 2015).

Posteriormente, a LC n. 132/2009 alterou radicalmente a LC 80/94, consolidando o movimento que buscava descolar a DP do campo da tutela individual dos necessitados em direção a outras atribuições, notadamente no campo da tutela coletiva e da promoção dos direitos humanos (BRASIL, 2009a).

Historiando a articulação que tornou possível a LC n. 132/2009, Moreira (2016, p. 109111) argumenta que a construção do diploma legal remonta ao início dos anos 2000 e foi capitaneada por um grupo de defensores da DP de São Paulo. A ideia que subjazia o projeto era, justamente, dar um novo perfil institucional ao órgão, no que o autor visualiza, pela primeira vez, um descolamento em relação ao modelo do MP e a busca de um caminho institucional próprio para a DP.

A estratégia em torno de um "novo perfil" encontrou êxito no Congresso Nacional e perante o Executivo. Apenas três vetos foram apresentados à LC n. 132/2009, nenhum que esteja associado a qualquer razão corporativa mobilizada pelo MP ou por outra instituição do sistema de justiça (BRASIL, 2009b). As inovações do diploma legal são muitas, abrangendo, entre outras: i) promoção da ACP e qualquer outra ação vocacionada à tutela dos direitos difusos, coletivos e individuais homogêneos quando o resultado da demanda puder beneficiar grupos de pessoas hipossuficientes (art. $\left.4^{\circ}, \mathrm{VII}\right)$; ii) promoção da defesa de direitos individuais, difusos, coletivos e individuais homogêneos dos necessitados em geral, do consumidor necessitado, da criança, do adolescente, do ídolo, da pessoa com deficiência, da mulher vítima de violência e outros grupos sociais vulneráveis que mereçam especial proteção do Estado (art. 4 , VII, VIII, X e XI); iii) a definição de objetivos da Defensoria Pública contemplando questões como a redução das desigualdades sociais, a afirmação do Estado Democrático de Direito e a garantia dos princípios constitucionais de ampla defesa e do contraditório (art. $\left.4^{\circ}-\mathrm{A}\right)$.

Além disso, embora o diploma normativo não deixe isso suficientemente claro, há uma clara guinada no discurso institucional da tutela dos "necessitados", isto é, pessoas sem capacidade financeira para a contratação de um advogado privado, para categorias mais abrangentes como "hipossuficientes" e "vulneráreis" (MOREIRA, 2016, p. 177). Em uma sociedade, como a brasileira, marcada por um profundo nível de desigualdade social, o manejo dessas categorias mais amplas sobrepõe quase integralmente o campo de atuação do MP e da DP no âmbito da tutela coletiva.

Do ponto de vista normativo, a coroação do longo processo de mudança institucional aqui descrito foi a promulgação da EC n. 80/2014. Através deste ato normativo, foi reconhecido constitucionalmente o caráter permanente da DP, sua função de "orientação jurídica, a promoção dos direitos humanos a e a defesa, em todos os graus, judicial e extrajudicial, dos direitos individuais e coletivos, de forma integral e gratuita, aos necessitados" (novo caput do art. 134 da CRFB/88). Também foram previstas a unidade, indivisibilidade e independência funcional como princípios 
institucionais (novo par. $4^{\circ}$ do art. 134). Por fim, estabeleceu-se, no art. 98, par. $1^{\circ}$, do ADCT a previsão de que, até 2022, todas as comarcas e seções judiciárias do País deverão contar com defensores públicos (BRASIL, 2014).

Todo esse cenário sinaliza que, tal como ocorreu com o MP no período entre 1970 e 1980, a agenda política da DP apostou, e obteve êxito, no problema crônico da efetividade de direitos no País (MARONA et al., 2017) como estratégia para buscar mais atribuições e, portanto, mais poder dentro do sistema de justiça, deixando em segundo plano a atribuição mais evocada durante a ANC, associada à atuação judicial na tutela individual, com especial ênfase no âmbito criminal. ${ }^{21}$ Nessa perspectiva, os deputados federais Mauro Benevides, Alessandro Molon e André Moura, proponentes da PEC n. 247/2013, que se converteu na EC n. 80/2014, consignaram em sua exposição de motivos que

A alteração do caput do art. 134 incorpora importantes elementos estruturantes e conceituais à definição do papel e da missão da Defensoria Pública, como o seu caráter permanente e ontologicamente atrelado ao modelo de Estado democrático de direito. Explicita-se, também, a sua vocação para a solução extrajudicial dos litígios, para a defesa individual ou coletiva, conforme a necessidade do caso, e para a promoção dos direitos humanos. (CÂMARA DOS DEPUTADOS, 2013).

Parece incorreto, portanto, que o movimento em busca de um novo perfil da DP viabilizado pela LC 132/2009 e, posteriormente, pela EC 80/2009 esteja dissociado de uma referência ao modelo do MP. Identificar essa imprecisão, contudo, depende fundamentalmente de uma abordagem comparativa. Assim, além de uma clara sobreposição de atribuições no campo da tutela coletiva - e, de certa maneira, também no que diz respeito à promoção dos direitos humanos -, propomos que a aposta da DP em uma guinada para esse novo desenho institucional ocorre de forma paralela a um outro fenômeno de mudança institucional gradual, mas no âmbito do Ministério Público, qual seja, um giro de prioridades do campo da tutela coletiva para a área da repressão penal à corrupção.

\footnotetext{
${ }^{21}$ Em manifestação na $5^{\text {a }}$ Sessão Ordinária da Subcomissão do Poder Judiciário e Ministério Público, durante a ANC, José Neves César, representante da FENADEP, assim ilustrou o caráter essencial da DP ao sistema de justiça: "o triângulo da Justiça tem muito bem aparelhado o organismo invértice, que é o Ministério Público e o Judiciário, e o vértice da defesa está quebrado, precisa ser solidificado, precisa ser-lhe dado o verdadeiro poder de defesa. Vejam V.Exa.'” que no juízo criminal, por exemplo, o povo diz comumente que cadeia e prisão foram feitos para o pobre. Por que pensam assim? É muito simples. Quando um cidadão de posse comete um crime, procura o seu advogado, é orientado como deverá defender-se, é acompanhado no inquérito policial, é marcado o dia para se apresentar ao delegado - o que geralmente fazer no dia anterior, para evitar a imprensa e as perguntas indiscretas dos delegados. O defensor público acompanha o pobre no momento em que ele já $\square$ foi preso, muitas vezes violentado, porque confessou, algemado, na frente do Juiz. Aí começa a atuação do defensor público. Precisamos acabar com isso. Não pode haver duas justiças: uma para o rico e outra para o pobre'. A Justiça é uma só . Nem a Defensoria Pública pode ser laboratório de experiência jurídica, nem o pobre pode ser cobaia no exercício dos seus direitos, É preciso que se faça uma Justiça una. A justiça do rico e do pobre tem que ser igual. Temos de evitar como aquele belo quadro que emoldura essa sala, em que o protomártir da Independência está recebendo a sentença -- que ao lado do pobre só $\square$ haja o poder de acusação, o poder de sentenciar e a ausência do defensor. A Justiça ampla e plena tem que ter aí presença do defensor público." (BRASIL, 1987, p. 101).
} 


\section{MP entre a tutela coletiva e o combate à corrupção: uma mudança institucional informal?}

\subsection{A tutela coletiva e a imagem positiva do MP no pós-1988}

Com a reconfiguração de seu quadro institucional concluída com a CRFB/88, verificou-se uma mudança significativa da imagem do Ministério Público perante a sociedade e, associado a isso, um acúmulo progressivo de capital político por parte da instituição. Nessa perspectiva, nos primeiros anos da década de 2010, o MP figurava como uma das instituições mais confiáveis aos olhos dos brasileiros, como demonstraram os dados do último trimestre de 2014 do Índice de Confiança na Justiça da Fundação Getúlio Vargas. Segundo a pesquisa, o Ministério Público figurava, à época, como a terceira instituição mais confiável, com $50 \%$ de manifestações positivas dos cidadãos entrevistados, atrás apenas das Forças Armadas e da Igreja Católica (CUNHA, 2012). Em se tratando de um órgão formalmente integrado ao sistema de justiça e formado por uma das elites do serviço público, este alto índice de confiança em face a outras instituições da República é dado intrigante e que tem mobilizado uma série de pesquisas acerca do MP nos últimos anos (RIBEIRO, 2017, p. 51-52).

Embora a CRFB/88 tenha confiado ao MP um número de atribuições sem precedentes na história da instituição e pouco comparável a agências congêneres na maior parte dos países assemelhados ao Brasil, o marco normativo em si não explica os porquês desse alto índice de confiança da população. Aqui, parecem concorrer uma multiplicidade de fatores, como a perenidade institucional e, sobretudo, a ampla capilaridade do órgão em todo o território nacional ${ }^{22}$, nomeadamente em um espírito do tempo que, como visto, mesmo antes da CRFB/88 já identificava no MP a função de uma espécie de advogado da sociedade. ${ }^{23}$ Nessa perspectiva, sustenta-se, na esteira de parte da literatura sobre o MP (ARANTES, 2002; MARONA et al., 2017), que, ao longo dos anos que se seguiram à Constituição de 1988 e do significativo aumento formal do rol de atribuições ministeriais, essa ampla visibilidade positiva da instituição foi mediada por um processo de construção de uma imagem institucional que mobiliza, dentre os diferentes campos de atuação confiados ao MP, uma agenda de prioridades como elemento central para a articulação da interação do órgão com a sociedade civil.

\footnotetext{
${ }^{22}$ Ao defender a absorção, pelo Ministério Público, da função de ombudsman cuja criação autônoma foi seriamente aventada nos trabalhos constituintes, Antônio Araldo Ferraz Dal Pozzo, então presidente da Associação Paulista do Ministério Público (APMP) e Secretário-Geral da Confederação Nacional do Ministério Público, declarou em audiência pública na Subcomissão do Poder Judiciário e do Ministério Público que "[...] o Ministério Público defende o interesse de seu titular, que é a sociedade. [...] Para a defesa desses valores, organizado em milhares e milhares de comarcas, por todo território nacional, o Ministério Público atua, basicamente, de três formas diferentes: fora do processo, na investigação e dentro do processo. Fora do processo, o Ministério Público desenvolve uma atividade preventiva e conciliatória. O povo conhece o Ministério Público, nele confia e o procura em seus gabinetes de trabalho. Os promotores de justiça vêm cumprindo, silenciosamente, há muitos anos, o papel do ouvidor do povo, do Ombudsman." (BRASIL, 1987, p. 105).

${ }^{23}$ Como referência histórica, observe-se o discurso de posse do último Procurador-Geral da República (PGR) do regime pré1988 e primeiro PGR da Nova República, José Paulo Sepúlveda Pertence, em março de 1985 que menciona a necessidade, no contexto de uma democracia política, da construção de um MP que, dentre as suas funções, abarque "a defesa da sociedade e dos direitos humanos, dos interesses indisponíveis dos oprimidos."
} 


\subsection{Voluntarismo político e defesa da sociedade: a autovisão do MP nos anos 1990}

O estudo seminal de Rogério B. Arantes, publicado em 2002, sobre a interação entre MP e política foi o primeiro a delinear as bases de uma certa "dimensão intencional da ação de promotores e procuradores no sentido de reconstruir o Ministério Público e transformá-lo em agente político da lei." (ARANTES, 2002, p. 115). Deve-se advertir, todavia, que esse projeto político não se deu à revelia ou paralelamente à Constituição. Há elementos suficientes, no desenho institucional do MP, para identificá-lo como uma instituição intencionalmente situada, pelo Constituinte, na fronteira entre a política e o sistema de justiça (ARANTES, 1999, p. 96). Um desses aspectos está relacionado à ampla liberdade assegurada aos membros do MP no desempenho de suas atribuições, a chamada independência funcional, podendo fazê-lo, inclusive, de ofício - o que distingue sensivelmente a instituição, por exemplo, do Poder Judiciário, que é submetido ao chamado princípio da inércia ${ }^{24}$ (LAMENHA, 2019).

Diante desse quadro institucional, Arantes (2002, p. 116-119), com base em dados colhidos em 1996 em sete estados da Federação no survey "O Ministério Público e a Justiça no Brasil" (SADEK, 2010), identifica, dentro da instituição, a presença de um discurso dominante que gravita em torno de uma certa ideologia institucional baseada na visão do órgão e da sociedade, no que o autor denomina como "voluntarismo político."

Nessa esteira, o voluntarismo político com aspecto central da cultura institucional do MP brasileiro estaria baseado em três características: i) uma leitura bastante crítica da sociedade, que seria incapaz de se mobilizar em torno dos direitos que lhe são assegurados pela legislação; ii) uma leitura bastante crítica do Estado e da classe política, que seriam incapazes de implementar os direitos assegurados pela legislação à sociedade; iii) a conclusão de que, diante de uma sociedade e um Estado divorciados e incapazes de funcionar adequadamente, caberia ao MP ocupar esse espaço e promover a tutela dos direitos dessa sociedade fragilizada.

Assim, considerando o cenário de desenvolvimento de uma teoria e de uma prática associados à disputa por uma agenda de direitos no âmbito do sistema de justiça, o que o survey de 1996 identificou foi que a autoimagem do MP como guardião dos interesses de uma sociedade débil foi mobilizada por agenda institucional que priorizou a atuação no campo da tutela coletiva em detrimento da função acusatória clássica do órgão (ARANTES, 2002, p. 118-119).

Analisando os dados do survey de 1996 (SADEK, 2010, p. 95), verifica-se que a hipótese do "voluntarismo político" proposto por Arantes tem base empírica. Chama atenção, nesse aspecto,

\footnotetext{
${ }^{24}$ Outros dois elementos que permitem afirmar que o MP está situado na fronteira entre o jurídico e o político são; i) a específica tarefa de defesa do regime democrático confiada ao MP; ii) a explícita rejeição, pela ANC, quanto à criação da figura do Defensor do Povo, à semelhança do ombudsman escandinavo ou do defensor del pueblo de alguns países hispanófonos e a decisão de integrar essas atribuições ao MP (LAMENHA, 2019).
} 
o índice de concordância total acerca de proposições sobre a debilidade da sociedade brasileira em mobilizar seus próprios interesses e a necessidade de uma instituição forte como o MP para mediação de conflitos e promoção de uma "conscientização". A título exemplificativo, 48\% dos promotores e procuradores entrevistados na ocasião concordaram integralmente com a afirmação de que 0 MP "deve desempenhar o papel de promoção da conscientização e responsabilidade da sociedade brasileira". 31\%, por sua vez, concordaram integralmente com a assertiva de que "sociedade brasileira é hipossuficiente, isto é, incapaz de defender autonomamente seus direitos", dependendo de instituições como o MP para protegê-la.

Em relação à avaliação dos membros sobre o desempenho da atuação do MP em diferentes campos, o survey de 1996 registrou, em primeiro lugar, a promoção da ação penal pública, com 83\% de resposta positiva dos entrevistados. Muito próximo, todavia, aparece justamente a defesa dos direitos transindividuais, com 77\% de análise positiva (SADEK, 2010, p. 90). O grande destaque dado à ação penal, vale ressaltar, provavelmente decorre do fato que se trata da atividade com maior volume quantitativo de trabalho, uma vez que a titularidade da ação penal pública é privativa do MP e sua atuação, mesmo nas ações penais privadas, é obrigatória. Assim, virtualmente, qualquer crime ocorrido que, eventualmente, se torne objeto de um processo judicial demandará necessariamente a atuação do órgão.

A principal chave utilizada por Arantes (2002, p. 116-119) para identificar uma agenda institucional voltada para a tutela coletiva, contudo, está associada às declarações relativas às prioridades pretéritas e futuras do órgão. Indagou-se aos entrevistados quais atribuições eles consideravam que foram tratadas como prioridades nos últimos 2 (dois) anos e quais seriam as prioridades para os próximos 2 (dois) anos. Aqui se verificou que, enquanto a identificação do foco na atuação criminal decresceu 11\% (onze por cento) entre os entrevistados, houve aumento em todos os campos associados à tutela de direitos difusos, coletivos e individuais homogêneos, com especial destaque para o meio ambiente (aumento de 12\%), os serviços de relevância pública (aumento de $17 \%$ ) e a improbidade administrativa (aumento de $22 \%$ ).

Algumas advertências merecem registro. Propor a existência de uma agenda de prioridades no cenário de um órgão com múltiplas e tão diferentes atribuições não significa que as atividades não prioritárias tenham sido deixadas totalmente de lado, ou ainda, que, quantitativamente, as atividades consideradas prioritárias representem o maior volume de trabalho desempenhado pelo órgão. O que se propõe, tão-somente, é a existência de um discurso dominante na construção da imagem do órgão, em meados da década de 1990, que o apresentava como um "advogado da sociedade" e especialmente vocacionado para a defesa de direitos transindividuais (SADEK, 2000, p. 30).

Como adverte o próprio Arantes (2002, p. 116), reconhecer a existência de um discurso dominante "não significa que divergências internas tenham desaparecido e, o que é mais importante, que a prática judicial e política inspirada nesses novos valores seja uniforme em todo o país." $\mathrm{Na}$ realidade, o desenho institucional do $\mathrm{MP}$ parece especialmente tendente a favorecer esse tipo de 
disputa: um rol significativo de atribuições e ampla liberdade de atuação, combinados com um modelo de baixa accountability (KERCHE, 2018). Acrescente-se que a pluralidade institucional, relativa à existência de 30 (trinta) órgãos ministeriais distintos nos diferentes níveis do sistema de justiça nacional, também é potencialmente reveladora da ausência uma agenda exatamente uniforme no âmbito dos diferentes MPs e abre espaço para a disputa entre visões diferentes quanto à instituição e a sua atuação.

Além disso, a lógica do voluntarismo político, associada à visão de um Estado e uma sociedade débeis dependentes de um MP forte e capaz de mediar conflitos e implementar direitos, não é intrinsicamente relacionada à temática da tutela coletiva, podendo ser mobilizada em direção a outras atribuições, a depender do quanto mudanças internas ou externas ao MP favoreçam uma nova agenda de prioridades (MARONA et al., 2017). Nessa perspectiva, Mahoney e Thelen (2010, p. 12) destacam que, mesmo sem alteração formal do quadro normativo, essa disputa de sentidos mobilizada por atores interessados em determinadas agendas é capaz de conduzir um processo gradual de mudança institucional. ${ }^{25}$ No caso do MP brasileiro, propõe-se que a tendência à consolidação de uma agenda baseada na defesa de direitos transindividuais foi revertida na direção de uma concepção mais clássica do papel do MP, vinculada a sua função acusatória e com foco particular na repressão à corrupção política.

\subsection{Um giro de prioridades: da tutela coletiva à repressão penal anticorrupção}

Se até meados dos anos 2000 uma das mais significativas novidades produzidas pelo novo quadro institucional da CRFB/88 se constituiu na possibilidade de implementação do catálogo constitucional de direitos e das políticas públicas a ele associadas através do Judiciário, verificou-se, a partir de então, uma progressiva inserção do MP em uma rede de accountability horizontal em franco desenvolvimento (O'DONNELL, 1998; ARANTES, 2015, p. 30), o que sobrelevou a sua atribuição, também prevista na CRFB/88, de fiscalização do patrimônio público, a partir da agenda de combate à corrupção.

A função ministerial de controle da administração pública já vinha ganhando destaque ao longo da década de 1990. O próprio estudo de Arantes, em 2002 (p. 154), dedica um capítulo à atuação do MP paulista no combate à corrupção e destaca os significativos resultados obtidos nesta seara. No entanto, a estratégia especializada de abordagem da questão da corrupção na época se dava,

\footnotetext{
${ }^{25}$ Dentre as quatro modalidades de mudança institucional gradual identificadas por Mahoney e Thelen (2010, p. 17-18), aludimos a que os autores denominaram como conversion, que "ocorre quando as regras permanecem formalmente as mesmas, mas são interpretadas de novas maneiras. Este espaço entre as regras e sua instanciação não é conduzido pela negligência a partir de uma alteração de configuração (como ocorre no drift); ao contrário, o espaço é produzido por atores que ativamente exploram as ambiguidades inerentes à instituição. Através da readaptação, eles convertem a instituição para novos objetivos, funções ou propósitos" (Tradução livre do texto "occurs when rules remain formally the same but are interpreted and enacted in new ways This gap between the rules and their instantiation is not driven by neglect in the face of a changed setting (as is true with drift); instead, the gap is produced by actors who actively exploit the inherent ambiguities of the institutions. Through redeployment, they convert the institution to new goals, functions, or purposes.").
} 
principalmente, a partir da esfera cível, com aplicação da recém promulgada Lei de Improbidade Administrativa (Lei n. 8.492/92), que era uma novidade. ${ }^{26}$ Isso explica porque o survey de 1996 inclui o controle da administração pública no campo dos direitos difusos, coletivos e individuais homogêneos, não o inserindo no âmbito criminal (ARANTES, 2002, p. 117). Dentre os resultados possíveis de uma condenação por ação de improbidade administrativa, destaca-se a sua dimensão de ressarcimento ao erário (embora seja possível um ato ímprobo que não envolva prejuízo aos cofres públicos), o que ressalta a sua dimensão associada aos direitos da coletividade. ${ }^{27}$ A repercussão penal dos fatos investigados em sede de fiscalização da administração pública, embora também presente na época - especialmente no âmbito da atuação dos MPs estaduais ${ }^{28}$-, não alcançava a mesma visibilidade, possivelmente em razão de entraves estabelecidos pela própria legislação de regência, como o foro de prerrogativa de função (ARANTES, 2002, p. 153) e a ausência de mecanismos processuais desenhados especificamente para o enfrentamento deste tipo de criminalidade.

Nesse aspecto, a grande novidade verificada a partir de meados dos anos 2000 foi a mobilização de um direito penal para o campo do combate à corrupção, não apenas quanto à repercussão penal de fatos investigados nesta seara, mas, especialmente, com o desenvolvimento de uma racionalidade especializada, e nacionalmente difundida, no enfrentamento deste tipo de delito (ARANTES, 2011, p. 99; AVRITZER; MARONA, 2017, p. 366), justamente a partir da articulação, para esse propósito, do MP com outras instituições de controle, como a recém-criada Controladoria-Geral da União, os Tribunais de Contas e as polícias judiciárias, em especial a Polícia Federal. Não é por acaso que datam do mesmo período iniciativas de cooperação como a Estratégia Nacional de Combate à Corrupção e Lavagem de Dinheiro (ENCCLA), criada em 2003, e a criação, no ano seguinte, do Departamento de Recuperação de Ativos de Cooperação Jurídica Internacional (LONDERO, 2019). É ilustrativo desse cenário que o número de operações de combate à corrupção

\footnotetext{
${ }^{26}$ A esse respeito, Arantes (2002, p. 153) destaca que "a Lei 8.429/92 é um desses marcos da judicialização da política no Brasil, na medida em que ampliou o acesso à justiça para ações contra ocupantes de cargos públicos. Para além das definições rigorosas de probidade e moralidade administrativas, a inclusão da fiscalização judicial implicou uma significativa redução da margem de discricionaridade da administração pública, ampliando enormemente as hipóteses de conflitos políticos desaguarem no Judiciário. Mas a Lei 8.429/92 não inovou apenas nesse ponto. [...] seu grande trunfo é permitir que os ocupantes de cargos executivos sejam processados sem o privilégio de foro especial [...] Do ponto de vista do Ministério Público, outra vantagem da Lei n. 8.429/92 é possibilitar que o grande contingente de promotores de justiça que atuam em primeira instância possam investigar (por meio do inquérito civil) e processar os ocupantes de cargos públicos situados em qualquer ponto dos ramos Executivo e Legislativo."

${ }^{27}$ Além disso, a maior parte da literatura especializada admite que o instrumento processual por meio do qual é veiculada a pretensão da improbidade administrativa é ação civil pública, instrumento típico de tutela coletiva (GARCIA; ALVES, 2013, p. 1482-1489).

${ }^{28}$ Datam desse período - meados da década de 1990 - as primeiras experiências do que viram a se tornar Grupos de Atuação Especial de Combate ao Crime Organizado (GAECOs), no âmbito dos MPs Estaduais. Vale ressaltar, todavia, que há época estes órgãos especializados não tinham um foco específico no controle penal da administração pública, mas sim de organizações criminosas em geral. Exemplos de especialização no campo da fiscalização do patrimônio público, como as chamadas Promotorias do Patrimônio Público, cuja criação também remontam ao mesmo período, possuíam, normalmente, atuação dúplice, isto é, cível e criminal.
} 
com a participação da Polícia Federal (e consequentemente do Ministério Público Federal) aumentou de 18, no ano de 2003, para 566, no ano de 2015 (AVRITZER; MARONA, 2016, p. 367). ${ }^{29}$

A conjuntura interinstitucional favorável associada a outros aspectos, como a natureza híbrida (cível e penal) dos ilícitos relacionados com a matéria-viabilizando uma narrativa institucional de que as preocupações com o campo da tutela coletiva não seriam deixadas de lado - e a difusão de uma agenda internacional associando boa governança ao combate à corrupção (FILGUEIRAS; ARANHA, 2011; MCCOY; HECKEL, 2001) por meio, inclusive, de tratados internacionais firmados pelo Brasil a esse respeito, ${ }^{30}$ são alguns dos fatores que podem explicar uma tendência a uma mudança institucional informal e gradual no âmbito do MP: de uma agenda prioritariamente centrada nos direitos transindividuais para o combate à corrupção, especialmente em sua vertente penal.

Essa tendência é amparada pela análise contextual de alguns achados de um outro survey, mais abrangente que o de 1996, realizado pelo Centro de Estudos de Segurança e Cidadania (CESeC) e coordenado, entre outros, pelas professoras Julita Lembruger e Ludmila Ribeiro. O estudo promoveu entrevistas, através de questionários, no período entre fevereiro de 2015 a fevereiro de 2016, com 899 membros do MP de todas as 30 (trinta) instituições ministeriais existentes no País, o que totaliza cerca de $7 \%$ do total de promotores e procuradores na ativa.

O voluntarismo político, proposto por Arantes em 2002, não só continua presente, como parece ter se reforçado. Essa conclusão é possível a partir da análise do nível de concordância total frente a algumas questões bastante semelhantes àquelas propostas no survey de 1996. Mais de um terço dos entrevistados (36\%) entende que a sociedade desconhece as atribuições do MP, um percentual um pouco superior àquele que concordou totalmente com a assertiva referente ao caráter indefeso da sociedade na pesquisa precedente (31\%). Além disso, em relação à função de promoção da cidadania e conscientização da sociedade, a pesquisa de 2016 encontrou números muito superiores a 2016: o índice aumentou de 48\% para 73,8\%.

Pode-se especular que os índices superiores que corroboram a hipótese do chamado voluntarismo político como ideologia institucional dominante no MP brasileiro, após um intervalo de 2 (duas) décadas entre os dois levantamentos de dados, decorrem de fatores como o grande afluxo de novos membros na instituição, já sob a égide do novo marco normativo da CRFB/88 (RIBEIRO, 2017, p. 61), além de, naturalmente, ter se desenvolvido maior familiaridade institucional com

\footnotetext{
${ }^{29}$ Aqui, por sinal, a limitação de dados disponíveis e a impossibilidade de abordar especificidades decorrentes da pluralidade de órgãos do MP existentes em todo país tem mobilizado a literatura sobre a instituição a tomar, como referencial primeiro, a experiência do Ministério Público Federal, dada a projeção e visibilidade de sua atuação decorrente do seu caráter nacional (AVRITZER; MARONA, 2016, p. 365-367; KERCHE; VIEGAS, 2020). Como já sugerido e será demonstrado a seguir, isso não invalida a possibilidade de mapeamento de uma trajetória institucional comum ao MP brasileiro. Sob outra perspectiva, é interessante observar que há quem identifique, na literatura, associada à transição da esfera cível para a esfera criminal (isto é, uma abordagem mais geral do fenômeno do giro de prioridades desde a tutela coletiva para a atuação criminal anticorrupção aqui proposto no campo específico do MP), uma espécie de transição da esfera estadual para a esfera federal no âmbito do sistema de justiça brasileiro (ARANTES, 2011, p. 99-101)

30 Veja-se, por exemplo, a Convenção Interamericana contra a Corrupção, internalizada por meio do Decreto n. 4.410/2002, e a Convenção das Nações Unidas contra a Corrupção, assinada pelo Brasil em 2003 e internalizada por meio do Decreto n. 5.687/2006.
} 
temas que, em meados da década de 1990, ainda constituíam uma novidade e um desafio em termos operacionais.

Nessa perspectiva, todavia, seria de se esperar que a tendência de priorização da tutela coletiva se mostraria consolidada no survey de 2016. Não é o que acontece. Corroborando a hipótese de mudança institucional gradual, um retorno à vocação acusatória do órgão, notadamente no campo do combate à corrupção, parece ter se traduzido como a agenda institucional que, na avaliação do MP, melhor reflete a sua missão de "advogado da sociedade".

Assim, dentre as áreas consideradas prioritárias para a atuação do órgão (o survey de 2016 não apresenta um comparativo entre análise pretérita e prognóstico futuro), $62 \%$ dos entrevistados inseriram o campo do combate à corrupção, seguidos de 49\% que indicaram a área da investigação criminal. Das matérias típicas do campo da tutela coletiva, apenas o meio ambiente figurou com um percentual acima de 40\%, com 45\% dos entrevistados indicando este como um campo prioritário da atuação do MP. Mesmo o direito do consumidor, outrora um dos carros-chefes da tutela coletiva no MP (o survey de 1996 indicava um percentual de 38\%), figurou com apenas 18\% dos membros ouvidos indicando-o como prioritário. Áreas historicamente problemáticas na concretização de direitos transindividuais, como patrimônio histórico e cultural, minorias étnicas e política fundiária, apresentaram percentuais muito baixos: 6\%, 4\% e 2\% respectivamente (LEMGRUBER et al., 2016, p. 29-30).

De mais a mais, sobre a visão dos membros acerca da qualidade do trabalho desempenhado pelo MP, isto é, o que a instituição desempenha com maior eficiência, atividades tipicamente relacionadas à função acusatória do MP foram melhor avaliadas. Cerca de $80 \%$ dos membros entrevistados classificaram a atuação no âmbito da ação penal como ótima ou boa, seguido de 76\% avaliando positivamente a atuação no campo da representação por ato infracional de menor. Das matérias típicas de tutela coletiva, destacam-se o meio ambiente, avaliado com $68 \%$, e a defesa do consumidor, com cerca de $66 \%$. O combate à improbidade administrativa, dimensão cível do combate à corrupção, figurou com 64\% (LEMGRUBER et al., 2016, p. 33).

Analisados conjuntamente, portanto, os dados do survey de 2016 autorizam a leitura de que os membros da instituição acreditam, majoritariamente, que atividades tipicamente associadas à função acusatória devem ser priorizadas pelo órgão. Esse achado representa uma reversão da tendência identificada em 1996, que sinalizava um crescimento da priorização da tutela coletiva acompanhado de um decréscimo da prioridade associada à atuação criminal. Curiosamente, contudo, quando levantada uma questão mais genérica sobre se, na opinião do entrevistado, a instituição dedica mais prioridade à atuação penal, a maioria dos ouvidos (51\%) respondeu negativamente à proposição (LEMGRUBER et al., 2016, p. 32). Isso talvez decorra do fato de que a grande maioria dos membros do MP entrevistados (63\%) atua parcial ou totalmente no campo da tutela coletiva.

Deve-se ponderar que o simples fato da maioria dos membros ter alguma atribuição no campo da tutela coletiva não é, por si só, indicativo de priorização da área. Do universo de 63\% dos 
promotores/procuradores com atribuição no campo, somente 38,8\% possuem atribuição exclusiva. Isso significa que a maioria (61,2\%) dos promotores/procuradores não atua com a matéria ou divide a atribuição com alguma outra (LEMGRUBER et al., 2016, p. 31). Neste último caso, tendo em conta o baixo nível de accountability associada à ampla independência funcional (KERCHE, 2018), na prática, os membros ficam livres para, em seu próprio ofício, priorizarem a matéria com que tem maior afinidade ou expertise. De mais a mais, considerando que a maior parte do trabalho na tutela coletiva se dá no âmbito extrajudicial, compromissos judiciais peremptórios, como prazos e audiências, tendem a preencher a agenda do promotor/procurador com atribuição mista, o que pode prejudicar a atividade na defesa de direitos transindividuais.

A extensão nacional do survey de 2016, abrangendo todas as instituições ministeriais do sistema de justiça, parece suficiente para propor que há suporte para a hipótese de mudança institucional informal de uma dominância discursiva e política da agenda da tutela coletiva para o campo anticorrupção, notadamente no seu aspecto de repressão penal, mesmo diante das especificidades decorrentes da pluralidade de órgãos do MP que convivem em todo País.

Embora a análise quantitativa de procedimentos e expedientes administrativos no âmbito do MP envolva limitações decorrentes do fato de que a mera instauração de um dado apuratório não mensura a qualidade e/ou efetividade de atuação nele desenvolvida, o trabalho de Sampaio e Viegas (2019) a partir da análise de um triênio (2015 a 2017) dos dados de produtividade de todos os órgãos do MP produzidos pelo Conselho Nacional do Ministério Público (CNMP) também dá suporte à hipótese aqui proposta.

O CNMP em seus relatórios anuais não aglutina as temáticas na dicotomia analítica aqui proposta: tutela coletiva x repressão penal anticorrupção. A classificação temática, inclusive, varia a depender do MP envolvido: se o MPF ou os MPs estaduais. De toda sorte, vejamos o acumulado dos dados do triênio nestes dois grupos distintos (MPF e MPs estaduais e distrital) e relativos a apuratórios de caráter investigativo (procedimentos preparatórios e inquéritos civis):

Tabela 1 - Número de inquéritos civis e procedimentos preparatórios instaurados no âmbito do Ministério Público Federal 2015/2017

\begin{tabular}{|c|c|c|c|c|}
\hline $\begin{array}{l}\text { Improbidade } \\
\text { administrativa }\end{array}$ & Patrimônio Público & Saúde & Educação & Serviço Público \\
\hline 31.490 & 13.440 & 12.664 & 10.454 & 5.784 \\
\hline
\end{tabular}

Tabela 2 - Número de inquéritos civis e procedimentos preparatórios instaurados no âmbito dos MPs Estaduais e Distrital 2015/2017

\begin{tabular}{ccccr}
\hline $\begin{array}{c}\text { Improbidade } \\
\text { administrativa }\end{array}$ & Meio Ambiente & Saúde & $\begin{array}{c}\text { ECA (Criança e } \\
\text { Adolescente) }\end{array}$ & Patrimônio Público \\
\hline 103.359 & 94.265 & 69.089 & 59.146 & 53.937 \\
\hline Fonte: Sampaio e Viegas $(2019$, p. 14), a partir de relatórios anuais do CNMP.
\end{tabular}

Fonte: Sampaio e Viegas (2019, p. 14), a partir de relatórios anuais do CNMP. 
A análise dos números totais evidencia que, embora haja alguma diferença do perfil atuação entre MPF e MPs Estaduais, com uma maior predominância de investigações anticorrupção no órgão federal (dados associados à "improbidade administrativa" e ao "patrimônio público"), em ambos os casos, a temática possui um número de apurações muito superior às demais catalogadas pelo CNMP, motivo pelo qual Sampaio e Viegas (2018, p. 22) propõem, entre outras conclusões, que é possível se verificar uma priorização de investigações anticorrupção na atuação extrajudicial dos MPs no plano federal e também estadual, ${ }^{31}$ corroborando ao menos o ponto de chegada da hipótese aqui proposta.

\subsection{Alguns efeitos da dominância da agenda anticorrupção no MP}

Não bastasse o comparativo entre as pesquisas de 1996 e 2016 evidenciarem uma reversão da tendência da priorização da tutela coletiva para o campo da função acusatória e que o combate à corrupção surge como prioridade máxima na agenda da maior parte dos membros, já há trabalhos na literatura descrevendo as alterações na estrutura organizacional interna dos Ministérios Públicos para priorizar uma atuação especializada na área de repressão penal anticorrupção. É o caso da criação de núcleos específicos para a temática - veja-se os Núcleos de Combate à Corrupção (NCCs), no âmbito do MPF, o Núcleo de Atuação Integrada no Combate à Corrupção (NAI-CC), do MPSP, e o Grupo de Atuação Especializada no Combate à Corrupção (GAECC), do MPRJ - e do desenvolvimento de uma expertise para a atuação através da sistemática de forças-tarefas ${ }^{32}$ e operações que, embora não constituam particulamente uma novidade em face da experiência dos GAECOs e outros órgãos especializados no âmbito dos MPs dos Estados, têm se aperfeiçoado dentro de uma lógica e de uma expertise direcionadas especificamente para o enfrentamento da criminalidade anticorrupção. ${ }^{33}$

Um outro aspecto a considerar está nos impactos institucionais, tanto internos quanto externos, dos grandes casos de corrupção, do qual a chamada Operação Lava Jato é um exemplo emblemático. $\mathrm{O}$ impacto deste tipo de atuação não repercute apenas na imagem institucional do MP, fortalecendo narrativas em torno da viabilidade de uma pretensa refundação da República a partir de um vigoroso esforço de repressão penal à corrupção por meio da condução das instituições do sistema

\footnotetext{
31 A mobilização destes dados a esta altura do texto, reitere-se, opera como elemento de reforço à hipótese da mudança institucional informal, de maneira que outras frentes de pesquisa podem oferecer outras perspectivas analíticas a respeito dos números expostos e do material produzido, anualmente, nos relatórios de produtividade do CNMP - denominados "Ministério Público: um retrato" e publicados desde o ano de 2012.

32 Segundo o Manual de Atuação da Escola do Ministério Público da União, em sua acepção mais geral, força-tarefa pode ser entendida como "uma equipe de especialistas dotada de meios materiais necessários à consecução de um objetivo específico, de reconhecida complexidade, e que recomende, por certo período de tempo, a coordenação de esforços de um ou mais órgãos, nacionais ou estrangeiros." (PALUDO et al., 2011, p. 28).

33 Tome-se aqui, a título exemplificativo, o histórico do GAECO do Ministério Público do Paraná. Seu nascedouro está nas Promotorias de Investigação Criminal, criadas pela Resolução n. 97/1994 e que, na prática, constituíra ofícios criminais especializados - mas abrangendo delitos em geral, e não apenas aqueles associados à repressão penal anticorrupção. Somente em 2007, com o advento da Resolução 1801, é que, sob a nomenclatura de GAECO, o órgão passa atuar na repressão específica da criminalidade organizada, dentre os quais "delitos praticados por agentes públicos no exercício da função, quando presentes características típicas de grupo criminoso organizado ou estruturado" - art. 5, II (MINISTÉRIO PÚBLICO DO PARANÁ, 2021).
} 
de justiça, como o MP (BARROSO, 2019, p. 167-176; CHALOUB; LAMENHA, 2019; LYNCH, 2018, p. 270-272), mas também proporciona a difusão de um novo instrumental de persecução que, de certa forma, concorre para uma certa "modernização da investigação criminal" no País (VIECILI, 2017).

Esse know how favorece não só uma maior eficiência em casos de maior complexidade, como tem o potencial de gerar efeitos na cultura institucional do MP mobilizando um maior interesse dos membros na atuação anticorrupção, especialmente focada na repressão penal. Do mesmo modo, não se pode desprezar que os efeitos da repercussão dos casos e da agenda anticorrupção seja identificado, à luz de um momento político em que o tema mobiliza fortemente a opinião pública, dentro da lógica do pluralismo estatal: tais narrativas e ampla visibilidade favorecem ao projeto institucional de busca de mais espaço e poder políticos.

\section{Conclusão}

Parece razoável propor que a agenda pública em torno da defesa e da promoção extrajudicial e judicial dos direitos transindividuais somente pode ser adequadamente compreendida se contemplar uma reflexão entre a dinâmica estabelecida entre MP e DP em torno da matéria, uma vez que o texto demonstra, à suficiência, a existência de uma clara sobreposição de atribuições entre as instituições nesse campo.

De mais a mais, também há evidências suficientes para propor que a DP, desde a sua constitucionalização, espelha muitos aspectos da trajetória de construção institucional do MP, notadamente a aposta no campo da tutela coletiva, como uma estratégia de consolidação do órgão no quadro institucional do sistema de justiça, livre do risco de reversão mobilizado pelo lobby de outras corporações, especificamente em relação à função primeira de orientação e defesa judicial dos necessitados.

Ao lado dessa trajetória desenvolvida pela DP nos anos que se seguiram à CRFB/88, há elementos suficientes para identificar uma mudança institucional gradual da agenda de prioridades do MP da tutela coletiva para a repressão penal à corrupção. Isso não significa que se trate de uma tendência irreversível, podendo ter sido motivada pelos últimos acontecimentos associados à conjuntura política (LEMGRUBER et al., 2016). O que parece certo, porém, é que esse movimento de mudança institucional informal ocorreu, de forma paralela, aos avanços da Defensoria Pública no processo de definição, pela legislação, de novas atribuições na temática da tutela coletiva ao órgão.

Não há evidência suficiente para apontar para uma relação causal entre esses dois processos, no entanto, é possível especular que a gradual mudança institucional do MP na direção da pauta penal/ anticorrupção pode ter sido percebida pelo DP na formulação de sua agenda corporativa posterior à EC 45/04, reeditando, em alguma medida, a mobilização do MP na década de 1970 e 1980, orientada pela tentativa de ocupar espaços no âmbito da tutela coletiva e da função promocional dos direitos 
humanos. ${ }^{34}$ Além disso, também é possível que o mesmo fenômeno possa ajudar a compreender, em algum nível, porque, diferentemente do ocorrido na CRFB/88 e na época da LC 80/94, a Defensoria Pública conseguiu implementar com sucesso toda a sua agenda corporativa a partir da EC n. 45/04.

Idealmente, a sobreposição de atribuições na tutela coletiva entre duas instituições do sistema de justiça sugere um fortalecimento no campo da defesa dos direitos transindividuais. É o que propôs, por exemplo, a processualista Ada Pellegrini Grinover (1984) em seu parecer apresentado pela ANADEP nos autos da ADI 3.943 (BRASIL, 2015). Indo além, o novo quadro normativo favoreceria atuações conjuntas - uma vez que a legitimação concorrente no âmbito da ACP, principal instrumento judicial no campo da tutela coletiva, não exclui a possibilidade de litisconsórcio -, o que, aliás, tem ocorrido em diversos casos em todo território nacional (OSÓRIO, 2019, p. 579-580).

Deixado um pouco de lado o panorama ideal, contudo, há dificuldades que recomendam a necessidade de pensar, com maior profundidade, a respeito da eficiência do modelo de sobreposição de atribuições na defesa de direitos transindividuais. Parece correto propor, de saída, que MP e DP não são instituições especializadas no campo da tutela coletiva, o que se deduz pelo simples fato de que os órgãos possuem outras atribuições que geram significativo e compulsório volume de trabalho. Observe-se, por exemplo, que o MP atua em todo e qualquer processo criminal no País (mesmo as ações penais privadas, na condição de fiscal da lei) e a DP está inexoravelmente atrelada à demanda oriunda os necessitados que demandam o órgão por tutela judicial e orientação jurídica nos mais variados campos do direito.

As demandas, sobretudo judiciais, estranhas à tutela coletiva em ambos os órgãos geram uma série de tarefas compulsórias: como prazos e audiências que ocupam a agenda diária dos promotores/procuradores e defensores, impedindo-os de atuar de forma mais constante no campo da defesa de direitos transindividuais, atividade que, por sua natureza, exige uma atividade extrajudicial intensa e diferenciada.

Poder-se-ia especular que a especialização interna, em ofícios específicos da tutela coletiva, poderia superar o problema, a exemplo do que já acontece no âmbito do MP. Essa solução, todavia, possui limitações claras. No âmbito específico da DP, tem-se que o nível de institucionalização e capilaridade da Defensoria no território nacional varia significativamente, sendo certo que várias comarcas/seções judiciárias do País sequer contam com um defensor público. No caso do MP, embora

\footnotetext{
${ }_{34}$ Também aqui há paralelos entre atribuições desempenhadas pelo MP e as mudanças normativas da DP ocorridas a partir do início dos anos 2000. Para além de um desdobramento natural na atuação na defesa de direitos transindividuais na direção de uma função promocional no campo dos direitos humanos, existe, na estrutura do Ministério Público Federal, a função do Procurador Federal dos Direitos do Cidadão (PFDC), que tem, por atribuição precípua, a defesa dos "direitos constitucionais do cidadão" e a garantia de seu efeito respeito pelos Poderes Públicos e pelos prestadores de serviço de relevância pública (LC 75/93, art. 14/16 e art. 40). No âmbito das unidades do MPF nos estados-membros, existem os Procuradores Regionais dos Direitos do Cidadão - PRDC e, no âmbito local, os Procuradores dos Direitos do Cidadão - PDCs (BRASIL, 1993). Paralelamente, após a promulgação da EC 80/2014, a Defensoria Pública da União (DPU), através de ato do seu Conselho Superior (Resolução n 127/2016), criou as funções de Defensor Nacional dos Direitos Humanos e Defensores Regionais dos Direitos Humanos. Dentre as numerosas atribuições confiadas a ambos os órgãos está, por exemplo, a interlocução (nacional e regional respectivamente) junto a outros órgãos e instituições, "visando à promoção dos direitos humanos e a defesa coletiva de direitos e interesses", conforme preveem os arts. $7^{\circ}$, IV, e 8 , XI do citado ato normativo (BRASIL, $2016 a$ ).
} 
a especialização interna já seja uma prática, ela efetivamente apenas é viável em localidades maiores, como capitais, de maneira que a acumulação das diferentes atribuições do órgão na figura de um único agente público é a realidade de um número significativo de comarcas do País (RIBEIRO, 2017, p. 62-64).

Além disso, ainda que haja experiências de sucesso na atuação conjunta de MP e DP na tutela coletiva, essa articulação depende, quase exclusivamente, da disposição dos agentes públicos envolvidos em torná-la possível. A ausência de um marco normativo que aborde a sobreposição de atribuições concorre para o risco de duplicidade de esforços estatais na direção de um mesmo problema, reproduzindo, em casos concretos, episódios de competição institucional em torno da tutela coletiva. Não se pode desconsiderar ainda o risco de que um conflito negativo de atuação, com ambas as instituições afirmando que a atribuição para atuar em um caso específico é da outra, postergando a efetiva proteção do direito transindividual em questão.

Direcionando a análise para as razões políticas que conduziram ambas as instituições para suas funções na tutela coletiva, deve-se considerar que, à luz do amplo catálogo de direitos positivado no ordenamento pátrio e da desigualdade estrutural existente na sociedade brasileira, a atuação na seara dos direitos transindividuais confere a tais instituições um papel político de peso na formulação e execução de políticas públicas em todos os níveis federativos. Virtualmente, portanto, qualquer assunto público pode ser mobilizado por ambos os órgãos como uma questão sob sua responsabilidade. Na chave do pluralismo estatal, a "defesa da sociedade" é um argumento político poderoso, que certamente favorece a obtenção de melhores condições e prerrogativas para as corporações e seus membros.

A combinação entre instituições não especializadas, que veem na reivindicação da posição de defensores da sociedade um trunfo político, e a idealização de uma atuação reforçada no campo da tutela coletiva decorrente da sobreposição de atribuições pode conduzir, na realidade, a um esvaziamento na defesa dos direitos transindividuais. Parece apressado, todavia, propor que a duplicidade de atribuições entre MP e DP no campo da tutela coletiva deveria ser inexoravelmente eliminada ou mesmo advogar por soluções mais drásticas, como a criação de uma instituição especificamente voltada para esse tipo de demanda ${ }^{35}$. As ponderações trazidas por este artigo procuram oferecer subsídios, à luz da teoria institucional, para que pesquisas posteriores, especialmente as que abordem empiricamente os resultados dessa superposição de funções, possam aprofundar a discussão.

\footnotetext{
${ }^{35}$ Ressalte-se aqui, a título de registro, que o Constituinte de 1987/1988 optou, já na fase de sistematização do texto constitucional, deliberadamente por não criar, ao lado do Ministério Público, uma agência independente voltada à defesa dos direitos do cidadão, nos moldes do ombudsman sueco ou do defensor del pueblo ibero-americano, como era defendido por alguns parlamentares constituintes, como José Paulo Bisol, autor da Emenda 32.069-6 a respeito do tema e de setores da sociedade civil, como a Confederação Nacional dos Bispos do Brasil (CNBB). Prevaleceu, contudo, na esteira da posição capitaneada pelo constituinte Ibsen Pinheiro, a solução de confiar tais funções ao MP que, na prática, já a exerceria mesmo sem mandato constitucional específico dada a capilaridade da instituição em todo o território nacional (SABELLA et al., 2013, p. 100-102; ARANTES, 2002, p. 87). A criação de uma instituição especificamente voltada para tutela coletiva necessariamente revisitaria este debate.
} 


\section{Referências}

ARANTES, Rogério Bastos. Direito e política: o Ministério Público e a defesa dos direitos coletivos. Revista Brasileira de Ciências Sociais, v. 14, n. 18, p. 183-102, 1999.

ARANTES, Rogério Bastos. Ministério Público e Política no Brasil. São Paulo: Sumaré, 2002.

ARANTES, Rogério Bastos. Polícia Federal e construção institucional. In: AVRITZER, Leonardo; FILGUEIRAS, Fernando (ed.). Corrupção e Sistema Político no Brasil. Rio de Janeiro: Civilização Brasileira, 2011.

ARANTES, Rogério Bastos. Rendición de cuentas y pluralismo estatal en Brasil: Ministério Público y Policía Federal. Desacatos, n. 49, p. 28-47, sept./dic. 2015.

AVRITZER, Leonardo; MARONA, Marjorie C. A tensão entre soberania e instituições de controle na democracia brasileira. Dados, v. 60, n. 2, p. 359-393, 2017.

BARROSO, Luís Roberto. Empurrando a história: combate à corrupção, mudança de paradigmas e refundação do Brasil (prefácio). In: PINOTTI, Maria Cristina. Corrupção: Lava jato e Mãos Limpas. São Paulo: Portfolio-Penguin, 2019. p. 9-19.

BRASIL. Ata da $5^{\text {a }}$ Reunião Ordinária da Subcomissão do Poder Judiciário e do Ministério Público na Assembleia Nacional Constituinte. Diário da Assembleia Nacional Constituinte, suplemento, Brasília, DF: Câmara dos Deputados, n. 78, 17 jun. 1987. Disponível em: http://imagem.camara.gov.br/ Imagem/d/pdf/sup78anc17jun1987.pdf\#page=97. Acesso em: 16 out. 2019.

BRASIL. Conselho Superior da Defensoria Pública da União. Resolução n. 127, de 06 de abril de 2016. Regulamenta a tutela coletiva de direitos e interesses pela Defensoria Pública da União. Diário Oficial da União, 19 abr. 2016a. Disponível em: https://www.dpu.def.br/conselho-superior/ resolucoes/30844-resolucao-n-127-de-06-de-abril-2016-regulamenta-a-tutela-coletiva-de-direitos-e-interesses-pela-defensoria-publica-da-uniao. Acesso em: 5 nov. 2019.

BRASIL. Constituição. República Federativa do Brasil de 1988. Brasília, DF: Senado Federal, 5 out. 1988. Disponível em: http://www.planalto.gov.br/ccivil_03/constituicao/constituicao.htm. Acesso em: 15 out. 2019.

BRASIL. Emenda Constitucional n. 45, de 30 de dezembro de 2004. Altera dispositivos dos arts. $5^{\circ}$, $36,52,92,93,95,98,99,102,103,104,105,107,109,111,112,114,115,125,126,127,128,129$, 134 e 168 da Constituição Federal, e acrescenta os arts. 103-A, 103B, 111-A e 130-A, e dá outras providências. Diário Oficial da União, Brasília, DF, 31 dez. 2004. Disponível em: http://www.planalto.gov.br/ccivil_03/constituicao/emendas/emc/emc45.htm. Acesso em: 10 out. 2019.

BRASIL. Emenda Constitucional n. 69, de 29 de março de 2012. Altera os arts. 21, 22 e 48 da Constituição Federal, para transferir da União para o Distrito Federal as atribuições de organizar e manter a Defensoria Pública do Distrito Federal. Diário Oficial da União, Brasília, DF, 30 mar. 2012a. Disponível em: http://www.planalto.gov.br/ccivil_03/constituicao/emendas/emc/emc69.htm. Acesso em: 10 out. 2019.

BRASIL. Emenda Constitucional n. 74, de 6 de agosto de 2013. Altera o art. 134 da Constituição Federal. Diário Oficial da União, Brasília, DF, 7 ago. 2013. Disponível em: http://www.planalto.gov. br/ccivil_03/constituicao/emendas/emc/emc74.htm. Acesso em: 10 out. 2019. 
BRASIL. Emenda Constitucional n. 80, de 4 de junho de 2014. Altera o Capítulo IV - Das Funções Essenciais à Justiça, do Título IV - Da Organização dos Poderes, e acrescenta artigo ao Ato das Disposições Constitucionais Transitórias da Constituição Federal. Diário Oficial da União, Brasília, DF, 5 jun. 2014. Disponível em: http://www.planalto.gov.br/ccivil_03/constituicao/emendas/emc/ emc80.htm. Acesso em: 10 out. 2019.

BRASIL. Lei Complementar n. 75, de 20 de maio de 1993. Dispõe sobre a organização, as atribuições e o estatuto do Ministério Público da União. Brasília, DF: Presidência da República. Disponível em: http://www.planalto.gov.br/ccivil_03/leis/lcp/lcp75.htm. Acesso em 12 out 2019.

BRASIL. Lei Complementar n. 80, de 12 de janeiro de 1994. Organiza a Defensoria Pública da União, do Distrito Federal e dos Territórios e prescreve normas gerais para sua organização nos Estados, e dá outras providências. Diário Oficial da União, 13 jan. 1994a. Disponível em: http://www. planalto.gov.br/ccivil_03/leis/LCP/Lcp80.htm. Acesso em: 12 out. 2019.

BRASIL. Lei Complementar n. 132, de 7 de outubro de 2009. Altera dispositivos da Lei Complementar n. 80, de 12 de janeiro de 1994, que organiza a Defensoria Pública da União, do Distrito Federal e dos Territórios e prescreve normas gerais para sua organização nos Estados, e da Lei n. 1.060, de 5 de fevereiro de 1950, e dá outras providências. Diário Oficial da União, Brasília, DF, 16 jan. 2009a. Disponível em: http://www.planalto.gov.br/ccivil_03/leis/LCP/Lcp132.htm. Acesso em: 12 out. 2019.

BRASIL. Lei n. 11.448, de 15 de janeiro de 2007. Altera o art. $5^{\circ}$ da Lei n. 7.347, de 24 de julho de 1985, que disciplina a ação civil pública, legitimando para sua propositura a Defensoria Pública. Diário Oficial da União, Brasília, DF, 16 jan. 2007. Disponível em: http://www.planalto.gov.br/ ccivil_03/_Ato2007-2010/2007/Lei/L11448.htm. Acesso em: 17 out. 2019.

BRASIL. Mensagem Presidencial n. 27/1994 - razões de veto à Lei Complementar n. 80/94. Brasília, DF, 12 jan. 1994b. Disponível em: http://www.planalto.gov.br/ccivil_03/leis/Mensagem_Veto/anterior_98/Vep-27-Lcp-80-94.pdf. Acesso em: 18 out. 2019.

BRASIL. Mensagem Presidencial n. 802/2009 - razões de veto à Lei Complementar n. 132/2009. Diário Oficial da União, Brasília, DF, 8 out. 2009b. Disponível em http://www.planalto.gov.br/ccivil_03/_Ato2007-2010/2009/Msg/VEP-802-09.htm. Acesso em: 24 out. 2019.

BRASIL. Supremo Tribunal Federal (Plenário). Ação Direta de Inconstitucionalidade n. 3.892/SC. Art. 104 da Constituição do Estado de Santa Catarina. Lei Complementar Estadual 155/1997. Requerente: Associação Nacional dos Defensores Pública da União (ANDPU). Relator: Min. Joaquim Barbosa, 14 de março de 2012b. Disponível em: http://redir.stf.jus.br/paginadorpub/paginador. jsp?docTP=TP\&docID=2822228. Acesso em: 2 nov. 2019.

BRASIL. Supremo Tribunal Federal (Plenário). Ação Direta de Inconstitucionalidade n. 3.943/DF. Art. $5^{\circ}$, inc. II, da Lei n. 7.347/1985, alterado pelo art. $2^{\circ}$ da Lei n. 11.448/2007. Requerente: Associação Nacional dos membros do Ministério Público (CONAMP). Relator: Min. Cármen Lúcia, 7 de maio de 2015. Disponível em: http://redir.stf.jus.br/paginadorpub/paginador.jsp?docTP=TP\&docID=9058261. Acesso em: 5 nov. 2019.

BRASIL. Supremo Tribunal Federal (Plenário). Ação Direta de Inconstitucionalidade n. 4.270/SC. Art. 104 da Constituição do Estado de Santa Catarina. Lei Complementar Estadual 155/1997. Requerente: Associação Nacional dos Defensores Públicos da União (ANDPU) e outro. Relator: Min. Joaquim Barbosa, 14 de março de 2012c. Disponível em: http://redir.stf.jus.br/paginadorpub/paginador.jsp?docTP=TP\&docID=2822228. Acesso em: 2 nov. 2019. 
BRASIL. Supremo Tribunal Federal (Plenário). Medida Cautelar na Ação Direta de Inconstitucionalidade n. 5.296. Art. 134, par. $3^{\circ}$, da Constituição. Requerente: Presidente da República. Relator: Ministra Rosa Weber, 18 de maio de 2016b. Disponível em: http://redir.stf.jus.br/paginadorpub/ paginador.jsp? docTP=TP\&docID=12013131. Acesso em: 2 nov. 2019.

CABRAL NETTO, Joaquim. CONAMP-CAEMP: uma história sem fim. Porto Alegre: Magister, 2009.

CÂMARA DOS DEPUTADOS. Projeto de Lei da Câmara n. 5.704, de 05 de agosto de 2005. Altera o artigo $5^{\circ}$ da Lei 7347, de 24 de julho de 1985 - Lei de Ação Civil Pública, para legitimar os Senadores, Deputados Federais, Deputados Estaduais e Vereadores para a sua propositura. Brasília, DF: Senado Federal, 11 ago. 2005. Disponível em: https://www.camara.leg.br/proposicoesWeb/fichadetramitacao?idProposicao=295407. Acesso em: 2 nov. 2019.

CÂMARA DOS DEPUTADOS. Proposta de Emenda Constitucional n. 237/2013. Brasília, DF: Câmara dos Deputados, 2013. Disponível em https://www.camara.leg.br/proposicoesWeb/fichadetramitacao?.idProposicao=567197. Acesso em: 4 nov. 2019.

CAPPELlETTI, Mauroz; GARTH, Bryant. Acesso à justiça. Porto Alegre: Fabris, 1988.

CARVALHO, Ernani; LEITÃO, Natália. O novo desenho institucional do Ministério Público e o processo de judicialização da política. Revista Direito GV, v. 6, n. 2, p. 399-422, dez. 2010.

CHALOUB, Jorge; LYNCH, Christian. O pensamento político-constitucional da República de 1988: um balanço preliminar. In: HOLANDA, Cristina Buarque de; VEIGA, Luciana Fernandes; AMARAL, Oswaldo (org.). A constituição de 88 trinta anos depois. Curitiba: Editora da UFPR, 2018. v. 1. p. 251-280.

CUNHA, Luciana Gross et al. (ed.). Relatório ICJ Brasil. Rio de Janeiro: Fundação Getúlio Vargas, $4^{\circ}$ trimestre de 2012. Disponível em: https://bit.ly/2rSEIvW. Acesso em: 1 jul. 2019.

MINISTÉRIO PÚBLICO DO PARANÁ. GAECO - Histórico. Disponível em: https://gaeco.mppr. mp.br/pagina-5.html. Acesso em: 27 maio 2021.

FILGUEIRAS, Fernando; ARANHA, Ana L. M. Controle da corrupção e burocracia da linha de frente: regras, discricionariedade e reformas no Brasil. Dados, v. 54, n. 2, p. 349-387, 2011.

GARCIA, Emerson; ALVES, Rogério Pacheco. Improbidade administrativa. 7. ed. Rio de Janeiro: Lumen Juris, 2013.

GRINOVER, Ada Pellegrini. Novas tendências na tutela jurisdicional dos interesses difusos. Revista da Faculdade de Direito - Universidade de São Paulo, São Paulo, n. 79, p. 283-307, 1984.

HALL, Peter A.; TAYLOR, Rosemary C. R. As três versões do neo-institucionalismo. Lua Nova, n. 58, p. 193-223, 2003.

HALL, Peter A.; TAYLOR, Rosemary C. R. Political Science and the Three New Institutionalisms. Political Studies, v. 44, n. 5, p. 936-957, 1996.

KERCHE, Fábio. Independência, Poder Judiciário e Ministério Público. Caderno CRH, v. 31, n. 84, p. 567-580, dez. 2018. 
KERCHE, Fábio; VIEGAS, Rafael. O Ministério Público: de defensor de direitos a combate da corrupção. In: ENCONTRO DA ASSOCIAÇÃO BRASILEIRA DE CIÊNCIA POLÍTICA, 12., 2020. Anais [...] 2020.

KERCHE, Fábio. Virtude e limites: autonomia e atribuições do Ministério Público no Brasil. São Paulo: Edusp, 2009.

LAMENHA, Bruno Jorge Rijo. A tarefa de defesa do regime democrático confiada ao Ministério Público brasileiro na Nova República: perspectivas a partir da noção de "contrademocracia"de Pierre Rosanvallon. In: ENCONTRO INTERNACIONAL PARTICIPAÇÃO, DEMOCRACIA E POLÍTICAS PÚBLICAS, 4., 2019, Porto Alegre. Anais [...] Porto Alegre, 2019. Disponível em: http://www. pdpp2019.sinteseeventos.com.br. Acesso em: 18 out. 2019.

LEMGRUBER, Julita et al. Ministério Público: Guardião da democracia brasileira? Rio de Janeiro: CESeC, 2016.

LONDERO, Daiane. Mudanças institucionais no âmbito do Ministério Público Federal no combate à corrupção no setor público brasileiro. In: ENCONTRO INTERNACIONAL PARTICIPAÇÃO, DEMOCRACIA E POLÍTICAS PÚBLICAS, 4., 2019, Porto Alegre. Anais [...] Porto Alegre, 2019. Disponível em: http://www.pdpp2019.sinteseeventos.com.br. Acesso em: 18 out. 2019.

MACIEL, Débora Alves; KOERNER, Andrei. O processo de reconstrução do Ministério Público na transição política (1974-1985). Revista Debates, v. 8, n. 3, p. 97-117, set./dez. 2014.

MADEIRA, Lígia Mori. Institutionalisation, Reform and Independence of the Public Defender's Office in Brazil. Brazilian Political Science Review, v. 8, n. 2, p. 48-69, 2014.

MAHONEY, James. Path dependence in historical sociology. Theory and Society, v. 29, n. 4. p. 507548, ago. 2000.

MAHONEY, James; THELEN, Kathleen. A theory of gradual institutional change. In: MAHONEY, James; THELEN, Kathleen. (ed.). Explaining institutional change: ambiguity, agency, and power. New York: Cambridge University Press, 2010. p. 1-37.

MARONA, Marjorie et al. O Ministério Público no contexto atual: de protagonista a ombudsman?. In: ENCONTRO ANUAL DA ANPOCS, 41., 2017, Caxambu. Anais [...] Caxambu, 2017. Disponível em: https://bit.ly/2AgtOlj; Acesso em: 30 set. 2018.

MCCOY, Jennifer L.; HECKEL, Heather. The emergence of global anti-corruption norm. International Politics, v. 38, p. 65-90, Mar. 2001.

MOREIRA, Thiago de Miranda Queiroz. A criação da Defensoria Pública nos Estados: conflitos institucionais e corporativos no processo de uniformização do acesso à justiça. 2016. Dissertação (Mestrado em Ciência Política) - Departamento de Ciência Polícia, Universidade de São Paulo, São Paulo, 2016.

NÓBREGA, Flavianne Fernanda Bitencourt. Entre o Brasil formal e o Brasil real: Ministério Público, instituição para o fortalecimento do Estado de direito? 2017 Dissertação (Mestrado em Ciência Política) - Programa de Pós-graduação em Ciência Política, Universidade Federal de Pernambuco, Recife, 2007. 
O'DONNELL, Guillermo. Accountability horizontal e novas poliarquias. Lua Nova, n. 44, p. 27-54, 1998.

OSÓRIO, Leticia Marques. Litígio estratégico em direitos humanos: desafios e oportunidades para organizações litigantes. Direito e Práxis, v. 10, n. 1, p. 571-592, mar. 2019.

PALUDO, Januário et al. Forças-tarefas: direito comparado e legislação aplicável. Brasília, DF: ESMPU, 2011.

PERTENCE, J. P. S. Discurso de posse como Procurador-Geral da República. Brasília, DF: [s. n.], 1985. mimeo.

RIBEIRO, Ludmila Mendonça Lopes. Ministério Público: velha instituição com novas funções? Revista Crítica de Ciências Sociais, n. 113, p. 51-82 set. 2017.

SABELLA, Walter Paulo et al. Memórias das lutas pela obtenção do texto do Ministério Público na Constituição de 1988. In: SABELLA, Walter Paulo et al. (org.). Ministério Público: vinte e cinco anos do novo perfil constitucional. São Paulo: Malheiros, 2013.

SADEK, Maria Tereza. Cidadania e Ministério Público. In: SADEK, Maria Tereza (ed.). Justiça e cidadania no Brasil. São Paulo: IDESP/Sumaré, 2000. p. 11-37.

SADEK, Maria Tereza (org.). O Ministério Público e a Justiça no Brasil. Rio de Janeiro: BVCE, 2010.

SAMPAIO, Marianna; VIEGAS, Rafael Rodrigues. Ministério Público: de fiscal a elaborador de políticas públicas. In: ENCONTRO DA ANPOCS, 43., Caxambu. Anais [...] Caxambu, 2019.

SAUWEN FILHO, João Francisco. O Ministério Público brasileiro e o Estado democrático de Direito. Rio de Janeiro: Renovar, 1999.

SENADO FEDERAL. Projeto de Lei do Senado n. 131, de 15 de abril 2003. Altera o artigo $5^{\circ}$ da Lei 7347, de 24 de julho de 1985 - Lei de Ação Civil Pública, para legitimar os Senadores, Deputados Federais, Deputados Estaduais e Vereadores para a sua propositura. Brasília, DF: Senado Federal, 2003. Disponível em: https://www25.senado.leg.br/web/atividade/materias/-/materia/56726. Acesso em: 2 nov. 2019.

SKOCPOL, Theda. Bringing the State Back. In: EVANS, Peter et al. (ed.). Strategies of analysis in current research. Cambridge: Cambridge University Press, 1985. p. 3-38.

VIECILI, Jerusa B. Lava Jato e modernização da investigação criminal no Brasil. Brasília, DF: Associação Nacional de Procuradores da República. 2017. Disponível em: https://bit.ly/2r2HD4A. Acesso em: 29 out. 2019. 